\title{
IDENTIFICAÇÃO DE RAÇAS \\ DE Xanthomonas spp. PATOGÊNICAS \\ A PIMENTÃO NO ESTADO DE SÃO PAULO
}

\author{
ROBERT WIERZBICKI
}

Dissertação apresentada à Escola Superior de Agricultura “Luiz de Queiróz”, Universidade de São Paulo, para obtenção do título de Mestre em Agronomia, Área de Concentração: Fitopatologia.

\author{
PIRACICABA \\ Estado de São Paulo - Brasil
}

Dezembro - 2004 


\title{
IDENTIFICAÇÃO DE RAÇAS DE Xanthomonas spp. PATOGÊNICAS A PIMENTÃo NO ESTADO DE SÃO PAULO
}

\author{
ROBERT WIERZBICKI
}

Biólogo

Orientador: Prof. Dr. JOSÉ OTAVIO MACHADO MENTEN

Dissertação apresentada à Escola Superior de Agricultura “Luiz de Queiróz”, Universidade de São Paulo, para obtenção do título de Mestre em Agronomia, Área de Concentração: Fitopatologia.

PIRACICABA

Estado de São Paulo - Brasil

Dezembro - 2004 


\section{Dados Internacionais de Catalogação na Publicação (CIP) DIVISÃO DE BIBLIOTECA E DOCUMENTAÇÃO - ESALQ/USP}

Wierzbicki, Robert

Identificação de raças de Xanthomonas spp. patogênicas a pimentão no Estado de São Paulo / Robert Wierzbicki. - - Piracicaba, 2004.

62 p. : il.

Dissertação (Mestrado) - - Escola Superior de Agricultura Luiz de Queiroz, 2004.

Bibliografia.

1. Bactéria fitopatogênica 2. Melhoramento genético vegetal 3. Pimentão 4. Pústula bacteriana 5 . Resistência genética vegetal I. Título

CDD 635.643

"Permitida a cópia total ou parcial deste documento, desde que citada a fonte - O autor" 
Aos meus pais,

Wieslaw Jan Wierzbicki e Maria Lúcia M. Wierzbicki,

pela centelha da vida e por terem me incentivado na busca do saber;

Aos meus avós,

Stefania Wierzbicki (“in memorian”) e Stanislaw Wierzbicki (“in memorian”) pelos aconselhamentos e exemplos de vida;

... e à toda a minha família pelo apoio e incentivo,

\section{Ofereço}

À minha esposa Silvana, e aos

meus filhos Ronald e Milene

pelo amor e compreensão

Dedico 


\section{AGRADECIMENTOS}

Aos Professores Dr. José Otávio Machado Menten e Dr. Luis Eduardo Aranha Camargo pela orientação, apoio e incentivo;

Aos Engs. Agrônomos Dr. Paulo Tarcísio Della Vecchia e Dr. Romulo F. Kobori pela orientação, apoio e incentivo;

Ao Prof. Dr. Antonio Carlos Maringoni pelo exemplo de profissionalismo e amizade;

Ao Prof. Dr. Ivan Paulo Bedendo pelo exemplo de profissionalismo e dedicação ao magistério;

Aos Professores do Departamento de Entomologia, Fitopatologia e Zoologia Agrícola da ESALQ/USP pelos ensinamentos;

Ao amigo Rock Seille Carlos Christinano pela amizade, apoio durante a estadia em Piracicaba, incentivo e auxílio na formatação do trabalho;

Aos amigos Waldir Cintra de Jesus Junior e Cleci Dezordi pela amizade e incentivo; 
Aos colegas do Laboratório de Biologia Molecular do Departamento de Fitopatologia - ESALQ/USP, Eng. Agrônoma Daniella Truffi e ao Biólogo Ademir Gazzotto pelo auxílio nos trabalhos realizados;

À Pesquisadora Dra. Alice M. Quezado Duval pelas informações e atenção dispensadas durante a elaboração dos trabalhos;

Aos funcionários do Departamento de Entomologia, Fitopatologia e Zoologia Agrícola da ESALQ/USP pela atenção dispensadas;

Aos funcionários do RUCAS - ESALQ/USP pela alimentação preparada e fornecida durante os anos de curso;

À todos os colegas do Departamento de Entomologia, Fitopatologia e Zoologia Agrícola da ESALQ/USP;

Aos colegas César A. Almeida, Elaine C. Capitan, Wellington B. dos Santos, Natália P. da Silva, Olga S. Suzuki da Sakata Seed Sudamerica pelo auxílio e apoio nos trabalhos realizados;

Aos demais funcionários do Departamento de Suporte Técnico da Sakata Seed Sudamerica pelo apoio indireto prestado;

À todos os colegas da Sakata Seed Sudamerica pela confiança em algum momento depositada;

À Escola Superior de Agricultura Luiz de Queiróz - USP pela oportunidade no aprendizado e na convivência;

À Sakata Seed Sudamerica pela oportunidade de realizar os estudos paralelamente ao trabalho; 
À todos que direta ou indiretamente contribuíram para a realização deste trabalho e que por descuido esqueci de mencionar;

À DEUS pela saúde, fé e paz concedidas... 


\section{SUMÁRIO}

Página

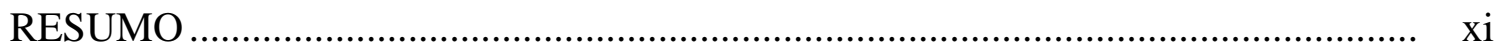

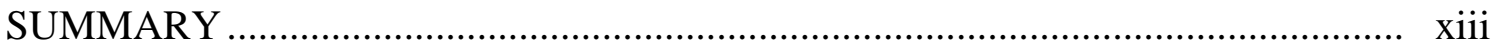

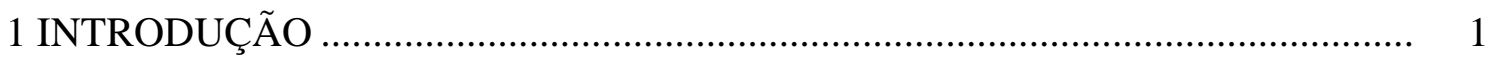

2 REVISÃO DE LITERATURA ....................................................................... 3

2.1 Importância da pústula bacteriana do pimentão................................................ 3

2.2 Natureza do agente causal da pústula bacteriana do pimentão ............................. 5

2.3 Identificação do Gênero Xanthomonas .......................................................... 8

2.4 Sintomatologia de Xanthomonas spp. em pimentão …................................... 9

2.5 Epidemiologia de Xanthomonas spp......................................................... 10

2.6 Patogenicidade de Xanthomonas spp. a pimentão e tomate................................. 13

2.7 As interações planta-bactéria no patossistema Pimentão-Xanthomonas spp......... 14

2.8 A Reação de Hipersensibilidade determinada por inoculação ............................. 17

2.9 Controle Genético da interação pimentão-Xanthomonas spp............................. 19

3 MATERIAL E MÉTODOS ............................................................................. 25 
3.1 Coleta de amostras de folhas de pimentão com sintomas de pústula bacteriana .... 25

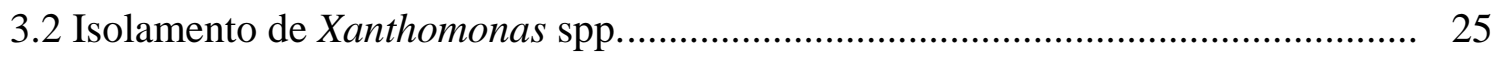

3.3 Genótipos diferenciais utilizados para a determinação de raças de

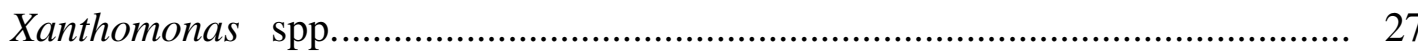

3.4 Experimentos para a determinação de raças fisiológicas de Xanthomonas spp., baseados em inoculação nos genótipos diferenciais......................................... 28

3.4.1 Origem e número dos isolados de Xanthomonas spp. obtidos......................... 28

3.4.2 Obtenção das plantas dos genótipos diferenciais ......................................... 29

3.4.3 Preparo do inóculo e inoculação dos genótipos diferenciais com

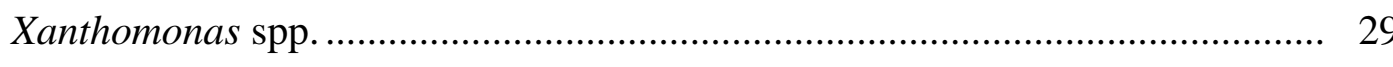

3.4.4 Avaliação dos sintomas de Xanthomonas spp. na série diferencial .................... 31

3.5 Método comparativo da avaliação de similaridade entre os isolados de

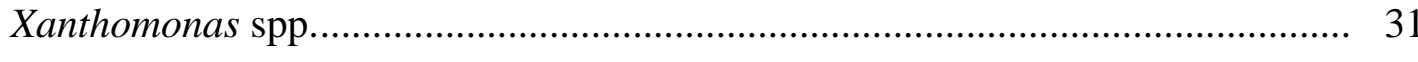

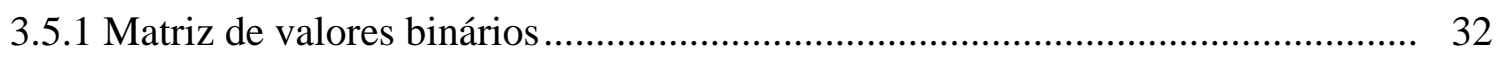

3.5.2 Obtenção da Matriz de Valores Binários ...................................................... 32

3.5.3 Obtenção da Matriz de Similaridades .......................................................... 34

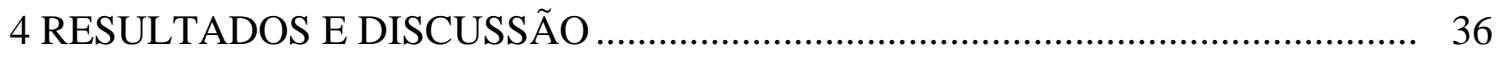

4.1 Identificação dos isolados de Xanthomonas spp............................................. 36

4.2 Experimentos para identificação de raças fisiológicas de Xanthomonas spp. baseados em inoculação nos genótipos diferenciais......................................... 38

4.3 Identificação das raças fisiológicas de Xanthomonas spp.................................. 47 


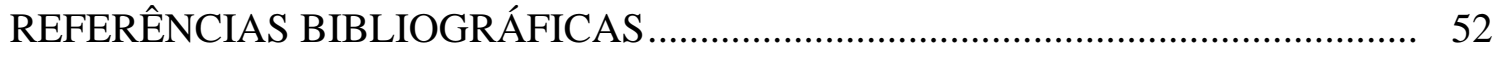




\section{IDENTIFICAÇÃO DE RAÇAS DE Xanthomonas spp. PATOGÊNICAS A PIMENTÃO NO ESTADO DE SÃO PAULO.}

Autor: ROBERT WIERZBICKI

Orientador: Prof. Dr. JOSÉ OTAVIO MACHADO MENTEN

\section{RESUMO}

A pústula bacteriana é uma das principais doenças que afetam o pimentão em todo o mundo. Seu agente causal pode ser disseminado por sementes, e é capaz de diminuir a produção e depreciar os frutos para comercialização. A bactéria Xanthomonas spp., o agente causal da doença, apresenta alta variabilidade. Três espécies estão associadas à doença: Xanthomonas axonopodis pv. vesicatoria, X. vesicatoria e $X$. gardneri. Enquanto alguns isolados infectam somente o pimentão, outros infectam pimentão e tomate. Xanthomonas axonopodis pv. vesicatoria é considerada a espécie mais comum em pimentão, e era anteriormente conhecida como o grupo A de Xanthomonas campestris pv. vesicatoria (A1 não amidolítico, A2 amidolítico); e o grupo B era representado por Xanthomonas vesicatoria (fortemente amidolítico). Até agora, 11 raças do patógeno foram relatadas, sendo as raças 1, 2 e 3 as mais comuns. A resistência genética tem sido a mais importante forma de controle e pode ser obtida pelo emprego de 4 genes dominantes (Bs1, Bs2, Bs3, Bs4). Estes genes estão associados à 
reação de hipersensibilidade e representam a forma mais promissora de resistência atualmente. Mesmo assim, o gene de resistência a ser utilizado depende da correta identificação das raças no campo. Este trabalho teve como objetivo a identificação de raças de Xanthomonas spp. isoladas em áreas de produção no Estado de São Paulo, visando o desenvolvimento e/ ou recomendação de cultivares resistentes. A identificação de raças do patógeno foi realizada através da observação da reação de hipersensibilidade em linhas quase isogênicas de pimentão Early California Wonder - ECW, ECW-10R, ECW-20R, ECW-30R; e na pimenta PI-235047. Os resultados obtidos entre os 41 isolados avaliados, indicaram a ocorrência das seguintes raças por região: raça 0 (Lins); raça 1 (Bacuriti); raça 2 (Bragança Paulista, Bacuriti, Lins, Ibiúna, Piacatu e Guaíra); raça 3 (Piedade); raça 7 (Mogi das Cruzes) e raça 8 (Piedade, Bragança Paulista, Bacuriti, Lins e Mogi das Cruzes). Pelos resultados, sugere-se o desenvolvimento e a recomendação de cultivares com o gene Bs2 para as regiões estudadas, pois este gene confere resistência às raças 0,1 , 2, 3, 7 e 8 do patógeno. 


\section{IDENTIFICATION OF RACES OF Xanthomonas sPp. PATHOGENIC ON PEPPER IN SÃO PAULO STATE, BRAZIL.}

Author: ROBERT WIERZBICKI

Adviser: Prof. Dr. JOSÉ OTAVIO MACHADO MENTEN

\section{SUMMARY}

Bacterial spot is one of the main diseases that affects the pepper worldwide. Its causal agent can be spreaded by seeds, and it is able to decrease the production and to depreciate fruits for commercialization. The bacteria Xanthomonas spp. the causal agent of bacterial spot is highly variable. Three species are associated to the disease: Xanthomonas axonopodis pv. vesicatoria, X. vesicatoria and X. gardneri. Some isolates infect only pepper and other infect pepper and tomato. Xanthomonas axonopodis pv. vesicatoria has been considered the most common species in pepper, and was formerly known as group A of Xanthomonas campestris pv. vesicatoria (A1 non amylolitic, A2 amylolitic) and group B represented by Xanthomonas vesicatoria (strongly amylolitic). Up to now 11 races of the pathogen have been reported and the races 1,2 and 3 are the most common. The genetic resistance has been the most important control method, through 4 dominant genes (Bs1, Bs2, Bs3, Bs4). These genes are associated to the hipersensitivity reaction and represent the most promising form of 
resistance nowadays. Even so, the resistance gene to be used depends on the correct identification of the races in the field. This work aimed the identification of the Xanthomonas spp. races in the São Paulo State from production areas, for the development and/ or recommendation of resistant cultivars. The identification of races of the pathogen was accomplished through the observation of the hypersensitivity reaction on near isogenic lines of Early California Wonder pepper - ECW, ECW-10R, ECW-20R, ECW-30R; and in the PI-235047 hot-pepper. Obtained results from 41 isolates, indicated the occurrence of the next races per region: race 0 (Lins); race 1 (Bacuriti); race 2 (Bragança Paulista, Bacuriti, Lins, Ibiúna, Piacatu and Guaíra); race 3 (Piedade); race 7 (Mogi das Cruzes); and race 8 (Piedade, Bragança Paulista, Bacuriti, Lins, Mogi das Cruzes). The results suggest the development and/ or recomendation of cultivars carring the Bs2 gene for studied regions, which confers resistance to 0, 1, 2, 3, 7 , and 8 races of the pathogen. 


\section{INTRODUÇÃO}

A produção de pimentão no Estado de São Paulo é uma das mais importantes dentre as culturas hortícolas. Os volumes produzidos atingiram entre 35.000 e $39.600 \mathrm{t}$. /ano entre 2000 e 2002. A cultura está sujeita a diversas doenças, dentre as quais destaca-se a pústula bacteriana, causada por Xanthomonas spp.

A doença pode causar redução significativa da produção e qualidade dos frutos, especialmente sob condições favoráveis, e pode ser eficientemente disseminada pelas sementes. A doença afeta folhas, caule e frutos através de lesões necróticas, podendo ocasionar queda precoce das folhas. Os danos diretos causados pelo patógeno correspondem a diminuição da área foliar e, por conseguinte, na diminuição da área fotossintética e depreciação de frutos para comercialização.

O patógeno pode sobreviver sem causar sintomas na cultura e dar início a uma epidemia quando as condições ambientes forem favoráveis. Estas incluem alta umidade e temperatura. Após a ocorrência do ciclo primário, a disseminação é rápida, dando origem a vários ciclos secundários, caracterizando a doença como policíclica. A disseminação do patógeno, como na maioria das bactérias, ocorre por respingos de água da chuva ou de irrigação por aspersão, ocorrendo também através dos tratos culturais. Estes tratos culturais incluem amarrio, colheita, entre outros.

O controle de Xanthomonas spp. no campo é difícil, assim como para a maioria das bactérias. O controle químico pelo uso de antibióticos, muitas vezes, não é eficiente devido a problemas como baixa absorção e penetração na planta, ou lavagem pela água 
da chuva e/ou irrigação. A forma inadequada de aplicação de produtos também pode diminuir a eficiência do controle. Além disso, o modo de condução das culturas com maior adensamento de plantas ou quando se utiliza irrigação por aspersão, também pode favorecer o desenvolvimento da doença. A ocorrência de variantes do patógeno resistentes à estreptomicina e ao cobre, também contribui para a ineficiência do controle químico.

A resistência genética representa uma importante estratégia no controle da doença. No entanto, apesar da existência de genes de resistência já descritos para diversas raças, as principais cultivares plantadas no Brasil não apresentam resistência ao patógeno.

De acordo com trabalhos realizados no Brasil e no exterior Xanthomonas spp. apresenta alto grau de variabilidade patogênica. O patógeno especializou-se em nível de raças fisiológicas, apresentando especificidade por cultivares/ linhagens dentro da mesma espécie. Atualmente estão descritas 11 raças, o que contribui para a dificuldade no controle da doença. A alta variabilidade do patógeno, aliada à ocorrência de condições ambientais favoráveis caracterizadas por calor e alta umidade, tornam ainda mais difícil o controle. No Brasil, já foram observadas em pimentão as raças: 0,1,2,3 e evidências das raças 7 e 8.

O presente trabalho teve como objetivo investigar a ocorrência de raças de Xanthomonas spp. que afetam a cultura do pimentão em diferentes regiões do Estado de São Paulo, através da inoculação em genótipos diferenciais.

Este trabalho poderá auxiliar no direcionamento dos programas de seleção de plantas e/ ou recomendação de cultivares com resistência genética ao patógeno. 


\section{REVISÃO DE LITERATURA}

\subsection{Importância da pústula bacteriana do pimentão}

A produção da cultura do pimentão no Brasil é uma das mais elevadas do mundo. O Estado de São Paulo é um dos maiores produtores do Brasil, produzindo 35000 toneladas/ ano em média nos últimos 05 anos (FNP, 2004).

O pimentão é uma hortaliça rica em vitamina A e potássio, que tem apresentado aumento real no consumo mundial e no Brasil. O consumo é feito principalmente "in natura” dos frutos verdes ou maduros (vermelhos), como também em forma de páprica, na elaboração de condimentos.

As plantas de pimentão estão sujeitas a diversas doenças (Tabela 1), dentre as quais destaca-se a pústula bacteriana, causada pela bactéria Xanthomonas campestris pv. vesicatoria (Doidge) Dye (Kimura, 1986). Este agente, será aqui às vezes representado por Xanthomonas axonopodis pv. vesicatoria (Starr and Garces) emend. Vauterin et al., (Xav), por ser de ocorrência mais comum em pimentão, ou simplesmente Xanthomonas spp.. 
Tabela 1. Principais doenças da cultura do pimentão (Lopes \& Ávila, 2003)

\begin{tabular}{cccccc}
\hline \multirow{2}{*}{ Doença } & \multicolumn{2}{c}{ Campo (Tipo de irrigação) } & \multicolumn{2}{c}{ Cultivo } & \multirow{2}{*}{ Pós-colheita } \\
& Aspersão & Sulco & Gotejo & Protegido & Pón \\
Antracnose & +++ & + & + & + & +++ \\
Pústula bacteriana & +++ & ++ & + & + & - \\
Mancha de Cercóspora & +++ & ++ & + & + & - \\
Mosaico & + & + & + & +++ & - \\
Murcha Bacteriana & + & +++ & ++ & +++ & - \\
Murcha de Escleródio & ++ & ++ & ++ & +++ & + \\
Murcha de Fitóftora & +++ & ++++ & ++ & ++++ & + \\
Nematóides das Galhas & + & + & + & ++ & - \\
Oídio & + & ++ & ++ & ++++ & - \\
Podridão Cinzenta & ++ & + & - & +++ & ++ \\
Podridão de Esclerotínia & + & + & + & ++ & + \\
Podridão mole & ++ & + & + & ++ & +++ \\
Vira-cabeça & ++ & ++ & +++ & ++ & - \\
\hline
\end{tabular}

$+=$ severidade da doença.

Entre as doenças bacterianas do pimentão (pústula bacteriana, murcha bacteriana e a podridão mole), descritas na Tabela 1, a pústula bacteriana apresenta-se como a mais importante sob condições de irrigação por aspersão, e como a segunda em ordem de importância em sistemas de irrigação de sulco ou gotejo.

O cultivo do pimentão em grandes áreas no Estado de São Paulo, tem sido feito principalmente em campo aberto, e em menores áreas, sob estufa. Plantios feitos sob condições de campo aberto - principalmente durante as épocas quentes e chuvosas, ou se o sistema de irrigação adotado for aspersão - tem favorecido o desenvolvimento da Pústula bacteriana (Lopes \& Ávila, 2003).

A variabilidade do patógeno dificulta o controle através da resistência genética, pois o patógeno se especializou em nível de raças. Diversas raças do patógeno já foram descritas (raça 0 à raça 10). Porém, genes de resistência às raças também foram encontrados (Bs1, Bs2, Bs3, Bs4), e têm sido propostos (bs5 e bs6). Desta forma, atualmente estão descritas 11 raças da bactéria, 4 genes que conferem a resistência do 
tipo “hipersensível” e 2 genes propostos recentemente, que conferem resistência do tipo “não hipersensível”.

\subsection{Natureza do agente causal da pústula bacteriana do pimentão}

Xanthomonas campestris pv. vesicatoria $(\mathrm{Xcv})$ causadora da Pústula bacteriana do pimentão (Capsicum annuum L.) é uma bactéria baciliforme (0,7 - 1,0 x 2,0 - 2,4 mm), Gram-negativa, aeróbia e móvel por meio de um flagelo polar. A bactéria pertence à família Xanthomonadaceae, com a característica marcante de formar colônias amarelas em meio de ágar nutritivo (NA) pela produção do pigmento denominado xanthomonadina (Lopes \& Soares, 1997).

A Xcv foi mencionada pela primeira vez em tomate em torno de 1914 em Pretória, África do Sul, e descrita como Cancro do Tomateiro (Doidge, 1920). Neste mesmo período, foi relatada em tomate nos Estados Unidos, uma doença semelhante chamada de "Bacterial Spot" (Gardner \& Kendrick, 1921); e em pimentão na Flórida, foi descrita a Pústula bacteriana do Pimentão (Sherbakoff, 1918). No Brasil, a doença foi relatada primeiramente por Batista (1947) na região Nordeste, causando sérios prejuízos em mudas e plantações de pimentão, e um pouco mais tarde, a doença foi constatada no Estado do Rio de Janeiro por Robbs (1953). Estudos comparativos entre os agentes causadores da Pústula bacteriana do Pimentão da Flórida, do Cancro do Tomateiro e da doença "Bacterial Spot”, confirmaram que estes eram estreitamente relacionados, mas diferiam em propriedades fisiológicas importantes (Higgins, 1922). Porém, outros estudos não apresentaram resultados conclusivos, fazendo com que os mesmos fossem

considerados como praticamente iguais (Gardner \& Kendrick, 1923). Devido à 
necessidade de definição da nomenclatura, estes autores propuseram que o patógeno fosse chamado de Bacterium vesicatorium Doidge.

A partir dos primeiros relatos, patógeno e doença receberam diversas denominações: Bacterium vesicatorium, causando o Cancro do Tomateiro (Doigde,1920); Bacterium exitiosa, causando “Bacterial Spot” (Gardner \& Kendrick, 1921); Pseudomonas vesicatoria, em 1925; Phytomonas vesicatoria, em 1930; Xanthomonas vesicatoria, em 1939; e, algumas vezes Xanthomonas campestris pv. vesicatoria (Jones et al., 1998).

Durante 04 décadas aproximadamente, acreditou-se que uma única espécie bacteriana causava esta doença em tomate e pimentão. Porém, a partir de 1990, a variabilidade do patógeno foi mais claramente demonstrada quando se observou que isolados provenientes de tomate hidrolisavam amido, e os de pimentão não (Burkholder \& Li, 1941; Maringoni, 1986). Dye (1966), observou também que isolados provenientes de pimentão hidrolisavam amido mais fracamente do que os provenientes de tomate.

A identificação da bactéria Pseudomonas gardneri (Sutic, 1957) em tomate, estabeleceu um variante, denominado Xanthomonas gardneri var. capsici envolvendo isolados que atacavam pimentão; porém, mais tarde, em estudos comparativos baseados em testes morfológicos e bioquímicos, estabeleceu-se ser sinonímia de $X$. vesicatoria. $X$. gardneri (Sutic, 1957) foi identificado na Iugoslávia e Costa Rica e recentemente no Brasil (Quezado-Duval et al., 2003) infectando tomate.

No Brasil, Kimura et al. (1972) sugeriram a criação de um quarto grupo, e Reifschneider et al. (1985) propuseram a divisão de $X v$ em oito grupos, todos baseados na reação dos hospedeiros diferenciais.

Os estudos da variabilidade do patógeno iniciados a partir de 1990, resultaram no emprego das mais variadas técnicas de identificação como: atividade amidolítica, expressão de bandas proteína-específicas, reação em hospedeiras diferenciais, reações padrão de anticorpos monoclonais, perfis de restrição de DNA, hibridização DNA-DNA 
(Jones et al., 1998); e outras técnicas baseadas em PCR e AFLP (Vauterin et al., 2000).O histórico da classificação, às vezes controversa, está descrito na Tabela 2.

Tabela 2. Histórico da classificação de Xanthomonas campestris pv. vesicatoria $(X C v)$ patogênicas a pimentão e tomate no período de 1990 a 2004

\section{Autores}

\section{Estudos/ Classificação}

Vauterin et al., $1990 \quad 02$ grupos geneticamente distintos;

Stall et al., 1994

Vauterin et al., 199502 grupos: $X$. vesicatoria $(X v$ - apresentam ativ. amidolítica - relac. à estirpe Tipo de $X c v) ; X$. axonopodis pv. vesicatoria (Xav - não apresentam ativ. amidolítica - relac. a outras estirpes);

Young et al., $1996 \quad$ X. vesicatoria (sinonímia de Xcv - conforme Vauterin et al., 1995);

Jones et al., $1998 \quad 02$ grupos genética e fenotipicamente distintos: Grupo A (Xav) e B $(X v)$. Grupo C relacionado ao A; Grupo D Xanthomonas gardneri - geneticamente distinto de A e B;

Vauterin et al., $2000 \quad 02$ espécies distintas: $X$. vesicatoria (forte ativ. amidolítica); $X$. axonopodis (ausência de ativ. amidolítica);

Jones et al., $2000 \quad$ estirpes de Xav que pertenceriam à estirpe Tipo de X. axonopodis (Vauterin et al., 2000) apresentaram menos de 70\% de homologia com esta espécie; 04 grupos fenotipicamente distintos e 03 espécies genômicas: Grupos A e C, Xav (C= subespécie de A); Grupo B, X.vesicatoria; Grupo D, X. gardneri;

Jones et al., $2004 \quad$ Grupo A $=X$. euvesicatoria; Grupo C=X. perforans sp. nov. $X$. gardneri $=$ estirpes do Grupo D com menos de $70 \%$ de homologia com outras spp. 


\subsection{Identificação do Gênero Xanthomonas}

A diferenciação entre bactérias Gram-negativas e Gram-positivas é de importância fundamental na identificação de gêneros bacterianos. O Gênero Xanthomonas, compreende espécies Gram-negativas como a maioria das espécies fitopatogênicas. A Técnica de Ryce (Suslow et al., 1982) é considerada um método alternativo em relação à Reação de Gram, apresentando como vantagens ser mais rápida e não utilizar corantes.

A utilização de meios seletivos e semi-seletivos também tem ajudado grandemente na identificação de isolados deste Gênero. De acordo com Schaad et al.(2001), a utilização de um meio semi-seletivo para Xanthomonas denominado YDC (Yeast Dextrose Carbonate) permite o crescimento de Xanthomonas spp. ao identificarse o crescimento de colônias amarelas neste meio. Segundo estes mesmos autores, o meio de cultura padrão em bacteriologia, o NA (Nutrient Agar), também identifica colônias de Xanthomonas campestris pv. vesicatoria através da cor amarela apresentada por suas colônias.

De acordo com a moderna classificação filogenética de bactérias, baseada principalmente em comparações de sequências nucleotídicas, principalmente do rRNA 16S, o gênero Xanthomonas pertence ao filo "Proteobacteria", classe "Gammaproteobacteria”, ordem "Xanthomonadales" e, conforme comentado, à família “Xanthomonadaceae” (Garrity \& Holt, 2000, citado por Quezado-Duval, 2003). 


\subsection{Sintomatologia de Xanthomonas spp. em pimentão}

Os sintomas da pústula bacteriana atingem a parte aérea das plantas, incluindo folhas, hastes e frutos. Os primeiros sintomas nas folhas são minúsculos pontos de coloração marrom-castanho. As manchas podem apresentar coloração verde-escuro, com aspecto de tecido encharcado (anasarca) que evoluem para necrose (Figuras 1A e 1B) e, como conseqüência, podem resultar em uma intensa desfolha (Figura 1C). A desfolha também pode expor os frutos à queimadura de sol (Figura 1E) (Higgins, 1922).
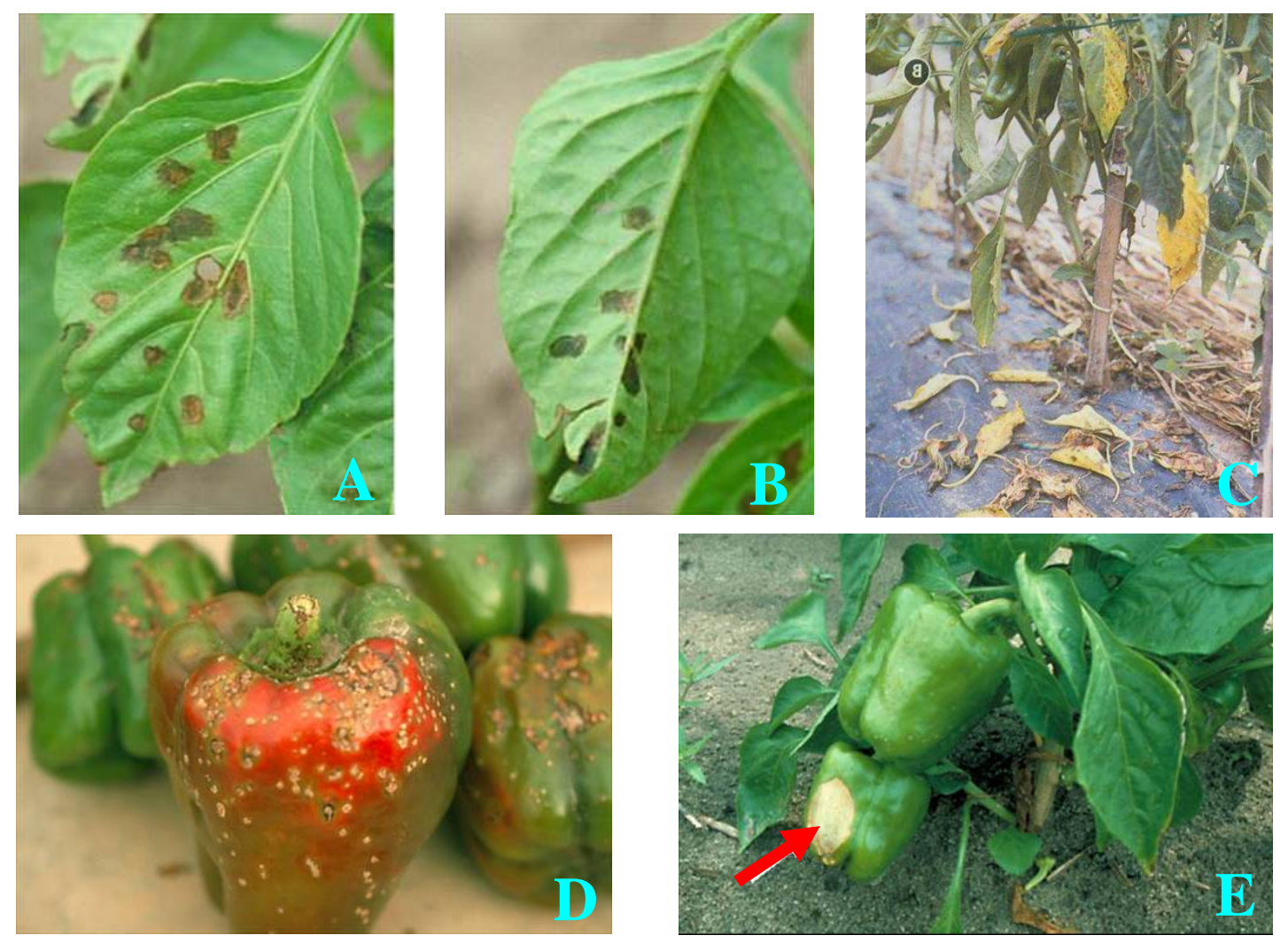

Figura 1 - Sintomas da doença causada por Xav em pimentão: lesões necróticas nas folhas (A e B); plantas com desfolha intensa (C), lesões necróticas nos frutos (D). Sintoma abiótico em fruto de pimentão “queimadura de sol” (E) 
Nos frutos, os sintomas começam com pequenas pústulas elevadas e esverdeadas, com aspecto irregular e áspero (Figura 1D.). A doença ocorre em qualquer estádio de desenvolvimento do pimentão, sendo mais prejudicial às mudas, em fase de viveiro, e às folhas e frutos de plantas adultas (Kimura, 1984).

\subsection{Epidemiologia de Xanthomonas spp.}

Nas condições brasileiras, a sobrevivência do patógeno ocorre em hospedeiros suscetíveis ou em folhas secas no solo, durante pelo menos 30 a 60 dias (Kimura et al., 1989). Provavelmente não sobrevive em restos de cultura incorporados ao solo por mais que dois ou três meses, pois apresenta baixa competitividade com microorganismos antagonistas ou que apresentem maior habilidade saprofítica no solo. O patógeno pode sobreviver também como residente na rizosfera e nas folhas de plantas não hospedeiras (Kimura et al., 1989).

O desenvolvimento como epífita em folhas de plantas hospedeiras e sua multiplicação sob condições de baixa umidade ou ambiente desfavoráveis, permite que o patógeno sobreviva, sem causar sintomas aparentes da doença, e que as epidemias ocorram quando as condições do ambiente tornam-se favoráveis (Bashan et al., 1982).

O patógeno pode ser disseminado através das sementes (Kimura et al., 1989; Salles et al., 1991), podendo espalhar-se desta forma com a ajuda do homem, a médias e longas distâncias, apesar de sua disseminação em campo ocorrer a curtas distâncias, como característica de patógenos bacterianos. Existem relatos de Xanthomonas spp. ter se mantido viável e patogênica em sementes contaminadas e armazenadas por mais de dez anos (Kimura, 1984). 
A infecção pela bactéria pode ocorrer por ferimentos, como microferimentos resultantes do atrito entre folhas pela ação dos ventos, ferimentos ocasionais pela ruptura de pêlos foliares ou pelo ataque de pragas, além de poder ocorrer pelos estômatos. Nos frutos, a ocorrência de pequenas rachaduras pode favorecer a doença (Hayward \& Waterson, 1964; Kimura, 1984). As fases iniciais da doença a partir das sementes (Figura 2A) encontram condições ideais de desenvolvimento durante as etapas de formação das mudas em bandeja, onde ocorrem umidade e temperaturas uniformes, além da favorável proximidade entre as plantas (Figura 2B).
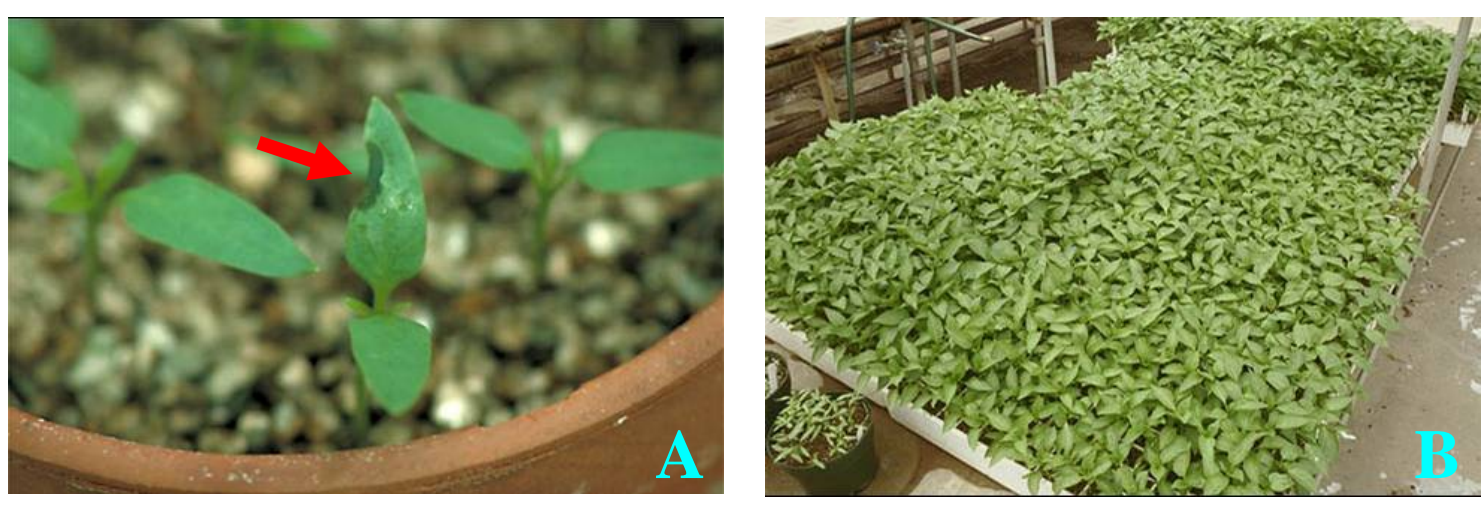

Figura 2 - Muda de pimentão com sintoma de anasarca causado por Xav (A). Mudas de pimentão em bandeja (B)

As condições ambientais que favorecem a ocorrência e o desenvolvimento da doença são alta umidade relativa e temperatura entre $22,5^{\circ} \mathrm{C}$ a $27,5^{\circ} \mathrm{C}$ (Cox et al., 1965; Morton, 1965). Períodos de alta umidade relativa (95\% a 100\%) e temperaturas entre $22^{\circ} \mathrm{C}$ e $32^{\circ} \mathrm{C}$, favorecem a infecção e o desenvolvimento da doença, podendo levar à desfolha intensa da planta (Diab et al., 1982; Kimura, 1984). Além disso, em períodos chuvosos, as infecções são mais freqüentes e as lesões se desenvolvem mais rapidamente em número e tamanho, levando à desfolha da planta (Kimura, 1984). Nos casos de chuvas prolongadas ou de irrigação por aspersão, principalmente acompanhadas de vento, podem ocorrer sérios prejuízos à lavoura. (Nayudu \& Walker, 1960; Hayward \& 
Waterson, 1964). Desta forma, considera-se também a maior importância da disseminação no sentido dos ventos predominantes durante as chuvas, conforme proposto por Walker \& Patel (1964).

A umidade, a temperatura, a precipitação e as variedades cultivadas, têm relação direta com a incidência da doença (Kimura, 1984). Temperatura contínua de $24^{\circ} \mathrm{C}$ ou temperaturas noturnas de $24^{\circ} \mathrm{C}$ a $28^{\circ} \mathrm{C}$ também favorecem o desenvolvimento da doença, ao passo que temperaturas inferiores a $16^{\circ} \mathrm{C}$ podem inibir seu desenvolvimento, mesmo que a temperatura e a umidade diurna sejam favoráveis. A doença também pode ocorrer entre $33^{\circ}$ e $35^{\circ} \mathrm{C}$ se a umidade relativa for elevada, mas não ocorre se a temperatura for superior a $35^{\circ} \mathrm{C}$ ou sob condições de baixa umidade relativa (Nayudu \&Walker, 1960).

Incluindo o pimentão e o tomateiro, outras plantas são consideradas hospedeiras de Xanthomonas spp., especialmente Solanáceas. Os hospedeiros incluem: Physalis minima, Datura stramonium var. Talula (Doidge, 1921), Capsicum frutescens (Gardner \& Kendrick,1923), Solanum tuberosum, Lycopersicon pimpinellifolium, Lycium halimifolium, Lycium chinense, Hyoscyanus niger, H. aureus, Nicotiana rustica, Solanum dulcamara, S. rostratum (Gardner \& Kendrick, 1921; Gardner \& Kendrick, 1923; Elliot, 1951; Dye et al., 1964; Hayward \& Waterson, 1964), tomate (Lycopersicon esculentum), pimentão (Capsicum annuum), “Chili Peppers” (Capsicum rutescens), Datura stramonium, Raphanus sativus, Physalis minima, S. nigrum, Nicandra physalodes e S. melongena (Elliot, 1951; Dye et al., 1964; Hayward \& Waterson, 1964; Kimura, 1976), Brassica oleracea var. Capitata (Frenhani, 1969) e Nicotiana tabacum L. (Kimura , 1986).

A doença distribui-se em todos os continentes do mundo (Hayward \& Waterson, 1964; Jones et al., 1998) e na maioria das regiões produtoras de tomate e pimentão dos estados brasileiros (Kimura et al., 1972; Robbs et al., 1981; Bongiolo Neto et al., 1986). 


\subsection{Patogenicidade de Xanthomonas spp. a pimentão e tomate}

As diferenças de sintomas que Xanthomonas spp. podem provocar inoculando-se isolados de tomate em pimentão e vice-versa, não eram até pouco tempo descritas na literatura, mas somente diferenças na quantidade de lesões em folhas das plantas inoculadas (Lucero, 1967).

Algumas estirpes de Xanthomonas spp. são virulentas às plantas de pimentão e tomate (Jones et al., 1998). Genótipos específicos de pimentão e tomate são importantes na caracterização de raças de Xanthomonas spp. patogênicas a estes hospedeiros. Genes de resistência à bactéria, existem em espécies de cada gênero (Capsicum e Lycopersicum), mas os genes não podem ser transferidos entre eles por hibridização natural (Jones et al., 1998).

Em pimentão estão descritas onze raças (P0 a P10) e em tomate, estão descritas três raças: a raça 1 (T1), a raça 2 (T2) e a raça 3 (T3). A raça T1 de Xanthomonas spp. de tomate apresenta maior habilidade de adaptação à Capsicum, por ser patógeno e causar hipersensibilidade em genótipos de Capsicum (Sahin, 1997). Esta habilidade provavelmente ocorreu devido à perda do gene avrBsT (Minsavage et al., 1990). A raça T2 é mais especializada no Gênero Lycopercicum, ocorrendo com frequência em Xanthomonas gardneri, que é patogênica a pimentão e tomate. A raça T3 é mais específica do tomateiro (Sahin, 1997).

De acordo com Quezado-Duval (2003), que analisou isolados de tomate no Brasil, membros de Xanthomonas gardneri ou foram patogênicos às plantas de tomate e pimentão, ou somente às plantas de tomate, tendo sido porém encontrados na Costa Rica, isolados patogênicos somente às plantas de pimentão (Bouzar et al., 1999; Quezado-Duval, 2003). 
Atualmente, isolados de Xanthomonas spp. são classificados em três grupos: o grupo de tomate $(X c v \mathrm{~T})$, somente patogênico a tomate; o grupo de pimentão ( $X c v \mathrm{P})$, somente patogênico a pimentão; e o grupo de tomate - pimentão (Xcv TP), patogênico a tomate e pimentão (Minsavage et al., 1990).

\subsection{As interações planta-bactéria no patossistema Pimentão-Xanthomonas spp.}

As interações planta-bactéria podem ser geralmente classificadas como compatíveis ou incompatíveis. Em uma interação compatível, uma planta hospedeira suscetível é infectada por uma bactéria virulenta (ou compatível), resultando na multiplicação e colonização da bactéria no tecido da planta infectada, e no aparecimento dos sintomas da doença. Em uma interação incompatível, uma bactéria avirulenta (ou incompatível), penetra uma planta hospedeira resistente ou uma planta não hospedeira, mas a multiplicação e colonização da bactéria são severamente restritas (Gopalan \& Yang He, 1996).

A principal característica de muitas interações incompatíveis é a ocorrência de morte rápida da célula da planta no local ou ao redor do sítio de infecção em questão, conhecida como reação de hipersensibilidade - RH (Klement, 1963; Goodman \& Novacky, 1994). A reação de hipersensibilidade (RH) em planta não hospedeira é o resultado de um gene de avirulência presente no patógeno (Cook, 1973; Canteros et al., 1991). A herança dos genes de resistência não está caracterizada, porque não há suscetibilidade em Lycopersicon às estirpes de pimentão, nem em Capsicum às estirpes de tomate. Porém, aceita-se que genes simples em pimentão e tomate são responsáveis pela resistência não hospedeira, porque tem-se observado que os genes simples de avirulência do patógeno avrBsT (Minsavage et al., 1990) e avr BsP (Canteros et al., 
1995), interagem com todas as plantas de Capsicum e Lycopersicon, respectivamente (Jones et al., 1998). Ainda não se sabe se a gama de hospedeiros observada para $X$. gardneri é, como no caso de Xav e Xanthomonas vesicatoria, igualmente determinada pelos genes de avirulência propostos por estes autores.

Os estudos dos genes de hipersensibilidade ( $H r p)$ envolvem as reações de hipersensibilidade e patogenicidade. Identificado em “clusters" de genes bacterianos (Niepold et al., 1985; Lindgren et al., 1986), estes genes podem elicitar a RH em plantas não hospedeiras ou causar doença em plantas hospedeiras. Outros estudos envolvendo hibridização DNA-DNA indicaram a universalidade dos genes Hrp, entre as bactérias gram-negativas, causadoras de necrose em plantas (Gopalan \& Yang He, 1996). Staskawicz et al. (1988), foi o primeiro a clonar um gene de avirulência de uma bactéria da soja. Ele mostrou que o gene avr clonado, poderia converter uma estirpe virulenta de Pseudomonas syringae pv. glycinea que causava doença, em estirpe avirulenta, que elicitava o gene $H R$ em certas cultivares de soja, que carregassem o gene correspondente de resistência.

A teoria gene-a-gene hipotetizada por Flor (1942), afirma que a resistência de uma determinada cultivar a uma determinada raça de fungo, é o resultado da interação entre o gene de avirulência do fungo ( $a v r$ ) e o gene de resistência do hospedeiro. Desta forma, este tipo de interação entre os genes de resistência das plantas e os genes de avirulência dos patógenos, limitariam a distribuição dos patógenos.

No caso das bactérias, duas classes de genes bacterianos podem sobrepor suas funções nos genes Hrp-mediadores de compatibilidade-incompatibilidade entre plantas e bactérias: os genes de avirulência ( $a v r$ ) e vários genes de virulência, sendo que o primeiro regula a incompatibilidade genótipo-específica em plantas resistentes e o segundo promove a produção dos sintomas necessários à virulência da bactéria. Alguns trabalhos indicaram que os genes avr dependem dos genes Hrp funcionais, para expressar seu genótipo (Gopalan \& Yang He, 1996). 
A identificação de genes de resistência em pimentão, associados com a reação de hipersensibilidade (Cook, 1973), permitiu uma aplicação direta na identificação destes genes através da indução da reação de hipersensibilidade. Desta forma, as relações planta-bactéria, através da interação entre os genes $H r p$ e os genes avr do patógeno, assumiram especial importância para a definição do método de identificação dos genes de resistência. Então, no patossistema pimentão - Xanthomonas spp., os genes avr estariam diretamente relacionados às raças do patógeno e os genes Hrp como mediadores de compatibilidade-incompatibilidade, conforme mostra a Tabela 3.

Tabela 3. Interação Genes Avr e Genes Hrp bacterianos associados aos genes de resistência em Xanthomonas spp. (Adaptado de Jones,1998)

\begin{tabular}{|c|c|c|c|c|c|}
\hline \multirow[b]{2}{*}{$\begin{array}{c}\text { Raças } \\
\left({\left.\text { Genes } A v r^{b}\right)}^{b}\right.\end{array}$} & \multicolumn{5}{|c|}{ Genótipos de Pimentão / Genes de Resistência ${ }^{a}$} \\
\hline & ECW & $\begin{array}{c}\text { ECW-10R } \\
(\text { Bs1) }\end{array}$ & $\begin{array}{c}\text { ECW-20R } \\
\text { ( Bs2 ) }\end{array}$ & $\begin{array}{c}\text { ECW-30R } \\
\text { ( Bs3 ) }\end{array}$ & $\begin{array}{c}\mathrm{PI}-235047 \\
(B s 4)\end{array}$ \\
\hline 0 (avrBs1, avrBs2,avrBs3, avrBs4) & $\mathrm{C}^{\mathrm{c}}$ & $\mathbf{I}^{\mathrm{c}}$ & I & I & I \\
\hline 1 (avrBs2, avrBs3, avrBs4) & $\mathrm{C}$ & $\mathrm{C}$ & $\mathbf{I}$ & $\mathbf{I}$ & $\mathbf{I}$ \\
\hline 2 (avrBs1, avrBs2) & $\mathrm{C}$ & $\mathbf{I}$ & $\mathbf{I}$ & $\mathrm{C}$ & $\mathrm{C}$ \\
\hline 3 (avrBs2, avrBs4) & $\mathrm{C}$ & $\mathrm{C}$ & $\mathbf{I}$ & $\mathrm{C}$ & $\mathbf{I}$ \\
\hline 4 (avrBs3, avrBs4) & $\mathrm{C}$ & $\mathrm{C}$ & $\mathrm{C}$ & I & I \\
\hline 5 (avrBs1) & $\mathrm{C}$ & $\mathbf{I}$ & $\mathrm{C}$ & $\mathrm{C}$ & $\mathrm{C}$ \\
\hline 6 (avrBs4) & C & C & C & $\mathrm{C}$ & I \\
\hline 7 (avrBs2, avrBs3) & $\mathrm{C}$ & $\mathrm{C}$ & $\mathbf{I}$ & $\mathbf{I}$ & $\mathrm{C}$ \\
\hline 8 (avrBs2) & $\mathrm{C}$ & $\mathrm{C}$ & $\mathbf{I}$ & $\mathrm{C}$ & $\mathrm{C}$ \\
\hline $9($ avrBs3) & $\mathrm{C}$ & $\mathrm{C}$ & $\mathrm{C}$ & $\mathbf{I}$ & $\mathrm{C}$ \\
\hline 10 nenhum gene $a v r$ conhecido & $\mathrm{C}$ & C & $\mathrm{C}$ & C & C \\
\hline
\end{tabular}

a- Genes de Resistência entre parênteses;

b- Prováveis genes de Avirulência entre parênteses;

c- C= Reação Compatível (suscetibilidade) / I= Reação Incompatível (resistência com RH). 


\subsection{A Reação de Hipersensibilidade determinada por inoculação}

Conforme definida como reação de incompatibilidade, para que ocorra a reação de hipersensibilidade (RH), algumas condições são necessárias: 1- Devem ser inoculadas células vivas; 2 - O potencial de inóculo deve ser elevado; 3 - As condições ambientes devem ser adequadas; 4 - O isolado deve ser patogênico; 5 - A planta inoculada não deve ser suscetível (Mariano, 2000). As condições ambientes adequadas dizem respeito ao nível de umidade relativa no local (\% U.R.) onde as plantas serão incubadas após a inoculação. As plantas não devem ser incubadas em ambientes com alta UR\%, uma forma prática de avaliar esta condição é através do tempo para o desaparecimento total do encharcamento no ponto de inoculação. Este período não deve superar a $10 \mathrm{~min}$. Se os sinais da inoculação persistirem por mais tempo, isto pode indicar excesso de umidade no local, o que pode ocasionar confundimento da reação de hipersensibilidade com a de susceptibilidade. De acordo com Cook \& Stall (1977), áreas encharcadas atrapalham o estabelecimento da RH. Posteriormente, estes mesmos autores atestaram a necessidade do contato direto das células bacterianas com as células da planta para que ocorra a RH (Stall \& Cook, 1979).

As técnicas de inoculação mais utilizadas nos trabalhos desenvolvidos com Xanthomonas axonopodis pv. vesicatoria são: injeção ou infiltração, aspersão ou atomização, e imersão no inóculo (“dipping”). A técnica de injeção (Klement,1963) (Figura 3), consiste em infiltrar cuidadosamente a suspensão bacteriana nos espaços intercelulares, abaixo da cutícula, na região contida entre duas nervuras laterais de folhas verdadeiras expandidas. Este método tem sido largamente utilizado para identificação de raças de Xanthomonas spp. em pimentão (Sahin \& Miller, 1996; Romero et al., 2002) e para a realização de testes de patogenicidade em plantas de fumo. As plantas inoculadas através do método de injeção não necessitam serem mantidas em câmara úmida após a inoculação. O método da imersão em inóculo é bastante utilizado para avaliação de resistência. As plantas devem ser imersas em uma suspensão de inóculo ajustada nas 
concentrações de $10^{5}, 10^{6}$ ou $10^{8} \mathrm{ufc} / \mathrm{ml}$ durante 15,15 ou 20 segundos, respectivamente, submetendo as plantas à câmara úmida por períodos variáveis de 48 h a 72 h (Kousik \& Ritchie, 1999; Romero et al., 2002). A técnica de inoculação através do método de aspersão (Figura 3C e 3D), é utilizada principalmente para caracterização da patogenicidade de isolados bacterianos (Sahin \& Miller, 1996). Esta técnica de inoculação é recomendada para bactérias que causam lesões foliares, e consiste em manter as plantas por $24 \mathrm{~h}$ a $48 \mathrm{~h}$ em câmara úmida para favorecer a abertura dos estômatos; adicionar algumas gotas de espalhante adesivo Tween-20 à suspensão bacteriana; inocular com um atomizador manual ou motorizado, ambos os lados das folhas até o ponto de escorrimento; manter as plantas em câmara úmida por 24 h e avaliar no período de 04 a 07 dias após a inoculação (Mariano, 2000).

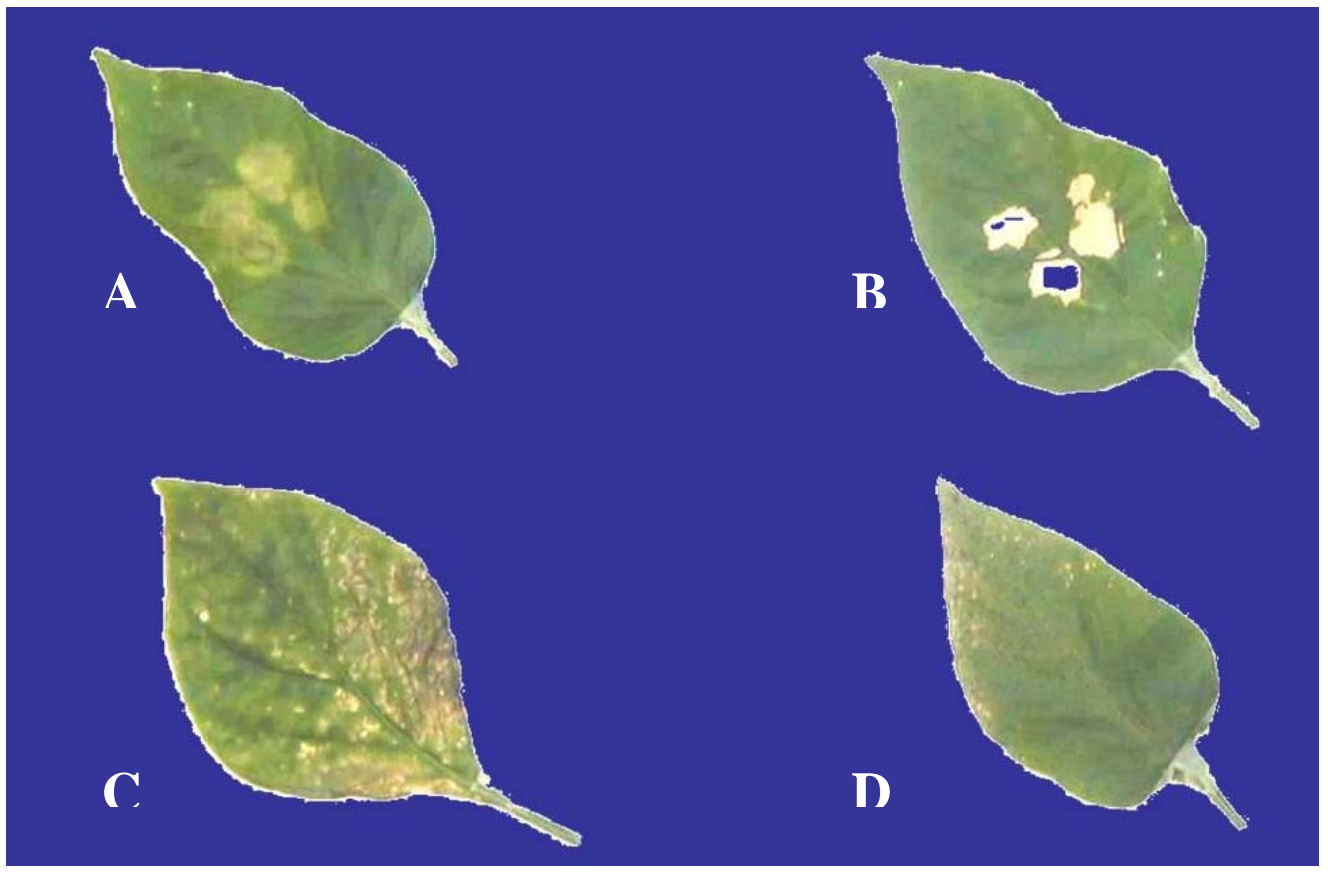

Figura 3 - Reação de folhas de pimentão à inoculação com Xanthomonas spp.: inoculação por infiltração em material suscetível (A), e resistente (B); inoculação por aspersão em material suscetível (C), e resistente (D) 
As concentrações ou padronização de inóculo adequadas estão diretamente relacionadas à técnica de inoculação utilizada. Em geral a concentração utilizada para a maioria das bactérias fitopatogênicas, bem como na maioria dos métodos de inoculação, varia entre $10^{6}$ e $10^{8} \mathrm{ufc} / \mathrm{ml}$ (Mariano, 2000). Os métodos de inoculação para a técnica de infiltração utilizam concentrações próximas ou iguais a $10^{8} \mathrm{ufc} / \mathrm{ml}$ (Sahin \& Miller, 1996; Mariano, 2000; Romero et al., 2002), ou até acima de $10^{8}$ ufc/ml (Romeiro, 2000). Os métodos de inoculação por aspersão podem utilizar concentrações bacterianas na fase logarítmica de crescimento, o que ocorre, após 36 h a 48 h de incubação da bactéria, sob condições de temperatura e nutrição ótimas (Mariano, 2000), ou ainda próximos ou iguais a $10^{8} \mathrm{ufc} / \mathrm{ml}$ (Sahin \& Miller, 1996; Romeiro, 2000).

Os períodos de incubação também podem variar de acordo com o que se quer avaliar. No caso da RH, geralmente após a inoculação por infiltração as plantas são incubadas por períodos de 12 h a 24 h (Mariano, 2000; Romeiro, 2000), ou 24 h a 48 h (Sahin \& Miller, 1996). Se o objetivo é avaliar sintomas de compatibilidade, os períodos podem variar de 2 a 7 dias (Sahin \& Miller, 1996; Mariano, 2000).

\subsection{Controle Genético da interação pimentão-Xanthomonas spp.}

A resistência genética é uma alternativa promissora no controle de Xanthomonas spp. Cultivares e híbridos de pimentão com um a três genes de resistência são usados comercialmente (Romero et al., 2002). Formas de resistência qualitativa (Hibberd et al., 1987; Minsavage et al., 1990; Jones et al., 2002) e de resistência quantitativa (Hibberd, 1987) têm sido descritas. Porém, a resistência qualitativa tem sido mais utilizada em cultivares comerciais, principalmente devido à facilidade de seleção (Kousik \& Ritchie, 1999). 
A principal estratégia em relação ao trabalho de resistência genética tem sido identificar genes de resistência associados com a reação de hipersensibilidade (Cook, 1973). Uma segunda estratégia utilizando a resistência da planta para o controle da doença é identificar genes que controlam a resistência não-hipersensível e usá-la em combinação com os genes de resistência associados à reação hipersensível (Jones et al., 2002).

A utilização da resistência vertical a Xanthomonas spp. em pimentão resulta em redução do nível de doença e aumento do rendimento, apesar da variabilidade do patógeno; e a resistência horizontal provoca a redução da taxa de doença, quando comparada à resistência vertical (Dahlbeck et at., 1979). O uso da resistência horizontal, por se tratar geralmente de um caráter poligênico necessita de métodos distintos de seleção, daqueles utilizados para a resistência vertical. De acordo com Walker (1965), para a triagem de materiais com resistência poligênica são necessárias condições ambientais ideais de temperatura, umidade e concentração de inóculo, pois os testes muito severos não permitem a expressão deste tipo de resistência.

Nelson (1978) sugeriu que a combinação de genes individuais de resistência a patógenos, em uma pirâmide genética, poderia proporcionar um "efeito residual” dos genes e uma maior durabilidade da resistência contra raças virulentas e avirulentas do patógeno. Esta teoria foi confirmada por Kousik \& Ritchie (1999) em trabalhos com Xanthomonas spp..

Atualmente, existem 11 raças que infectam pimentão descritas na literatura (Minsavage et al., 1990; Ritchie et al., 1998; Sahin \& Miller, 1998), baseando-se na reação de hipersensibilidade $(\mathrm{RH})$ em três linhas quase isogênicas da cv. Early California Wonder (ECW) de Capsicum annuum L. e em C. pubescens PI-235047 . Cada linha de Capsicum annuum L. carrega um gene distinto de resistência (Bs1, Bs2 ou Bs3) e C. pubescens o último gene proposto denominado Bs4 (Sahin \& Miller, 1998).

As isolinhas de ECW são: ECW - suscetível a todas as raças de pimentão conhecidas; ECW-10R, ECW-20R, ECW-30R e o PI-235047 que apresentam genes de 
resistência para raças específicas (Tabela 4). A raça 10 originou-se provavelmente a partir de estirpes que quebraram a resistência conferida pelo gene Bs4 (Ritchie et al., 1998). A identificação de dois genes recessivos de resistência, denominados bs5 e bs6, derivados de PI-271322 e PEP 13, respectivamente, foi proposta por Jones et al.(2002).

Tabela 4. Série diferencial utilizada na identificação de raças de Xanthomonas spp. patogênicas ao pimentão e respectivos genes de resistência

\begin{tabular}{ccc}
\hline Linhagem & Gene de Resistência & Resistência \\
\hline ECW -10 & Bs1 & Raças 0, 2 e 5 \\
ECW -20 & Bs2 & Raças 0, 1, 2, 3, 7 e 8 \\
ECW -30 & $B s 3$ & Raças 0, 1, 4, 7 e 9 \\
PI -235047 & Bs4 & Raças 0, 1, 3, 4 e 6 \\
ECW & Nenhum & Suscetível \\
\hline
\end{tabular}

* Não há resistência descrita para a raça 10.

A inclusão do PI-235047 como linhagem diferencial de raças, permitiu que raças que eram anteriormente classificadas como 1 e 3 , passassem a ser classificadas como raças 7 e 8, respectivamente, de acordo com a reação de resposta deste genótipo (Ritchie et al., 1998; Sahin \& Muller, 1998).

Existe uma variabilidade considerável no grupo Xanthomonas spp. patogênicas a pimentão e tomate (Jones et al., 1998). Os genes de avirulência presentes nos patógenos são sujeitos a mutação ou perda e, como muitos deles estão localizados em plasmídeos, podem ser trocados naturalmente, através de conjugação entre estirpes. Desta forma, as raças resultantes, não são necessariamente estáveis (Canteros et al., 1995). Altas taxas de mutação são descritas para avrBs1 (Dahlbeck \& Stall, 1979) e avrBs2 (Swords et al., 1996), o que resulta na “quebra” dos genes de resistência Bs1 e Bs2, respectivamente. A perda do plasmídeo contendo o gene avrBs3, também resulta em quebra do gene de 
resistência Bs3 (Minsavage et al., 1990). A diversidade nos padrões de plasmídeos em número e tamanho, bem como a mobilidade, impedindo a definição de um padrão de plasmídeo característico para Xanthomonas spp., foi demonstrado por Canteros et al. (1995). O que se observa, é que todos os genes para resistência ao patógeno foram vencidos, por pelo menos uma raça (Kousik \& Ritchie, 1999).

As cultivares que carregam o gene Bs2 são consideradas as mais promissoras porque o gene confere resistência às raças mais comuns (raças 1, 2 e 3) do patógeno. Este gene também é considerado o gene mais durável, porque a maioria das estirpes carrega o gene de avirulência avrBs2 (Kearney et al., 1988) e porque a inativação do gene avrBs2 reduz a taxa de multiplicação de algumas estirpes, em condições de laboratório (Swords et al., 1996). Este último autor também não relata a presença do gene avrBs2 em plasmídeo, o que pode favorecer a estabilidade das estirpes que carregam este gene. Sob condições de campo, ainda, as estirpes que possuem o gene avrBs2 permanecem agressivas. Estudos têm sido feitos avaliando-se a possibilidade da transferência do gene de resistência Bs2 de pimentão para plantas transgênicas de tomate. Isto poderia agregar valor à resistência em tomate, considerando-se infecções com estirpes que contenham o gene avrBs2 (Tai et al., 1999).

A “quebra” da resistência, conferida pelos genes de resistência no campo, também pode ser favorecida por outros fatores. O estresse hídrico, causando murcha nas plantas de pimentão, pode favorecer a “quebra” dos genes de resistência principal, como ocorreu em cultivos de pimentão comercial na Flórida (Pernezny et al., 1998), uma vez que as plantas estão permanentemente sujeitas à forte pressão de seleção exercida pelas raças no campo. O gene Bs2 em plantas de pimentão cultivadas em temperaturas de $32^{\circ} \mathrm{C}$ ou mais, também pode apresentar instabilidade fenotípica (Romero et al., 2002).

A maior parte das estirpes identificadas na década de 1990 carregava um ou mais genes de avirulência (Porhonezny et al., 1992), embora na raça 6, até 1996, não tenha sido identificado nenhum gene de avirulência (Sahin \& Miller, 1996). Hoje, somente a raça 10 não apresenta nenhum gene de avirulência conhecido. Dois genes de avirulência 
(avrBs1 e avrBs3) estão presentes em plasmídeo (Jones et al., 1998) e podem ser perdidos ou mutados (Dahlbeck \& Stall, 1979), resultando em genes inativos. O uso da resistência genética associada à reação de hipersensibilidade, tem sido reduzido devido ao surgimento da raça 10 em campos comerciais, uma vez que esta raça não apresenta nenhum gene de avirulência, o que determinaria a resistência nas plantas.

De acordo com a maioria dos trabalhos realizados, as raças 1 e 3 são as prevalentes no campo (Sahin \& Miller, 1996). Outros trabalhos desenvolvidos no Brasil relataram a ocorrência da raça 2 de Xanthomonas spp. em pimentão (Kobori \& Wierzbicki, 2000).

No Brasil, estudos que envolveram a inoculação de isolados infectando naturalmente o tomateiro, em uma série diferencial de Capsicum spp., inferiram a ocorrência de raças de pimentão em combinação com raças do tomateiro. Este trabalho, indicou a presença provável do gene avrBs2 (raça 08) observado juntamente com os genes: avrBs1 e avrBs2 (raça 02), na Região Nordeste; e com os genes avrBs2 e avrBs3 (raça 7) no Brasil-Central (Quezado-Duval, 2003). Também foi observada a ocorrência dos genes: avrBs1 e avrBs2 (raça 02) no Brasil-Central. Este mesmo autor relatou a presença de combinações entre genes avrBsP e avrBsT de Xanthomonas spp. de pimentão e de tomate, indicando a ocorrência das raças T1 e T2 de tomate, em combinação com as raças 2, 7 e 8 de pimentão nas regiões Nordeste e Brasil-Central. As espécies de Xanthomonas spp. identificadas neste trabalho, que apresentaram genes avrBsP identificados foram: Xanthomonas axonopodis pv. vesicatoria (T1P2) e (T1P8) e Xanthomonas gardneri (T2P7 e T2P8). A ocorrência de Xanthomonas gardneri no mundo tem sido relacionada às raças T2P1 e P1(Bouzar et al., 1999); e portanto, mais recentemente no Brasil-Central, às raças T2P7 e T2P8. De acordo com Sahin (1997), Xanthomonas gardneri tem apresentado patogenicidade a pimentão e tomate. No relato de Bouzar et al. (1994), isolados brasileiros foram identificados como raças T1P0, T1P2, T2, T2P1 е T2P3. 
A utilização de pirâmides genéticas, como alternativas para a resistência, indicou efeito residual dos genes de resistência Bs1 + Bs3 e Bs1 + Bs2 + Bs3 no comportamento de isolinhas que continham estes genes, sobre as isolinhas que continham os genes individualizados Bs1, Bs2 ou Bs3, quando inoculados com as respectivas raças. A utilização de pirâmides, porém, é controversa devido à possibilidade de ocorrência de uma “super-raça” que “quebre” todos os genes de uma só vez.

A descoberta de dois genes recessivos de resistência, não ligados à reação de hipersensibilidade, portanto, não associados à resistência oferecida pelos genes ligados à reação de hipersensibilidade, apresentou resultados favoráveis em experimentos realizados, sendo denominados bs5 e bs6 (Jones et al., 2002). 


\section{MATERIAL E MÉTODOS}

\subsection{Coleta de amostras de folhas de pimentão com sintomas de pústula bacteriana}

Diversas amostras de folhas de plantas de pimentão com sintomas característicos de pústula bacteriana, foram coletadas de campos comerciais durante os anos de 2000 e 2001. As coletas foram realizadas em regiões produtoras do Estado de São Paulo, envolvendo os municípios de Lins, Bacuriti, Mogi das Cruzes, Piedade, Ibiúna, Bragança Paulista, Piacatú e Guaíra. As coletas foram realizadas de forma aleatória nos campos de produção, evitando-se a coleta de folhas com sintomas de uma mesma "reboleira” (próximas).

\subsection{Isolamento de Xanthomonas spp.}

Os patógenos foram isolados de fragmentos de tecido foliar, de regiões periféricas de uma única lesão por amostra. A assepsia superficial foi feita durante 5 minutos, mergulhando-se os fragmentos obtidos em: álcool a 70\%, seguido de hipoclorito de sódio 2,5\% 3:1 (v:v) e realizada uma lavagem em água esterilizada, obtendo-se, em seguida, um macerado dos fragmentos de tecido em água esterilizada. O 
macerado assim obtido, foi transferido diretamente para placas de Petri contendo Nutriente Ágar - NA (Peptona - 10 g, Extrato de Carne - 03 g e Ágar - 20 g por litro de água); e YDC - Yeast Dextrose Carbonate (Extrato de Levedura - 10 g, Dextrose - 20 g, Carbonato de Cálcio 20g e Ágar - 18 g por litro de água) ( Sahin \& Miller, 1996). Após a transferência, as placas foram incubadas a $28^{\circ} \mathrm{C}$ por 02 dias. Foram avaliados: o hábito de crescimento, a coloração e a contaminação das colônias nas placas, e realizados testes pelo método de Ryce ( $\mathrm{KOH} 3 \% \mathrm{p} / \mathrm{v})$ para confirmar se as bactérias eram Gram negativas. Este método consiste em transferir, assepticamente, com um palito de dente esterilizado, uma porção da colônia bacteriana a ser avaliada para uma gota de solução de $\mathrm{KOH}(3 \%$ p/v), em uma lâmina limpa, flambada e esfriada ao ar. Em 15 segundos, com agitação circular, o resultado pode ser obtido: para bactérias Gram-positivas, as células dispersam-se na gota e não há aumento da viscosidade da suspensão, mantendose uma consistência fluída; para bactérias Gram-negativas, a suspensão torna-se viscosa, com a formação de um fino fio de muco, semelhante a clara de ovo, quando o palito é afastado lentamente da lâmina. Colônias individuais, circulares, convexas, mucóides e amarelas em meio YDC foram selecionadas, diluídas em água estéril quando necessário, e tranferidas para placas contendo o mesmo meio. O meio de NA foi utilizado também como uma referência para se avaliar possíveis contaminações por outras bactérias. Foram realizadas inoculações para se assegurar a patogenicidade dos isolados antes de armazená-los. Estas inoculações foram realizadas em plantas de pimentão cv. Magda suscetíveis à pústula bacteriana, pulverizando-se uma suspensão de colônias bacterianas obtidas após diluição das colônias em placas de Petri, após 48 h de crescimento em meio NA, nas faces inferior e superior das folhas de plantas entre o $3^{\circ}$ e $4^{\circ}$ par de folhas. Foi realizada câmara úmida nas 24 h antecedentes e nas 48 h posteriores à inoculação; e nebulização durante 72 h após a inoculação. A avaliação dos testes de patogenicidade foi feita em seguida, através da observação de lesões necróticas nas folhas inoculadas. Os isolados obtidos foram preservados em água destilada esterilizada e mantidos em geladeira $\left(7^{\circ} \mathrm{C}\right.$ a $\left.9^{\circ} \mathrm{C}\right)$ e em condições ambientes $\left(23^{\circ} \mathrm{C}\right.$ a $\left.30^{\circ} \mathrm{C}\right)$ com recuperações a cada 06 meses. Os isolados foram recuperados de acordo com um cronograma estabelecido para cada experimento. 


\subsection{Genótipos diferenciais utilizados para a determinação de raças de Xanthomonas} spp.

Como padrão de suscetibilidade foi utilizado o pimentão cv. Early California Wonder (ECW), que não possue nenhum gene conhecido de resistência à Xanthomonas spp. (O’Garro et al., 1999). As linhas quase-isogênicas ECW-10R, ECW-20R e ECW30R, que contêm os genes Bs1, Bs2 e Bs3, respectivamente (Hibberd et al., 1987), além da pimenta Capsicum pubescens PI-235047, que contém o gene Bs4 (Sahin \& Miller, 1996), foram utilizadas como genótipos diferenciais para a determinação das raças, com base em seus sintomas de suscetibilidade ou resistência. As reações esperadas dos genótipos são apresentadas na Tabela 5.

Tabela 5. Reação de genótipos diferenciais de pimentão em relação às raças de Xanthomonas spp., adaptada de Sahin (1997) e Ritchie et al. (1998)

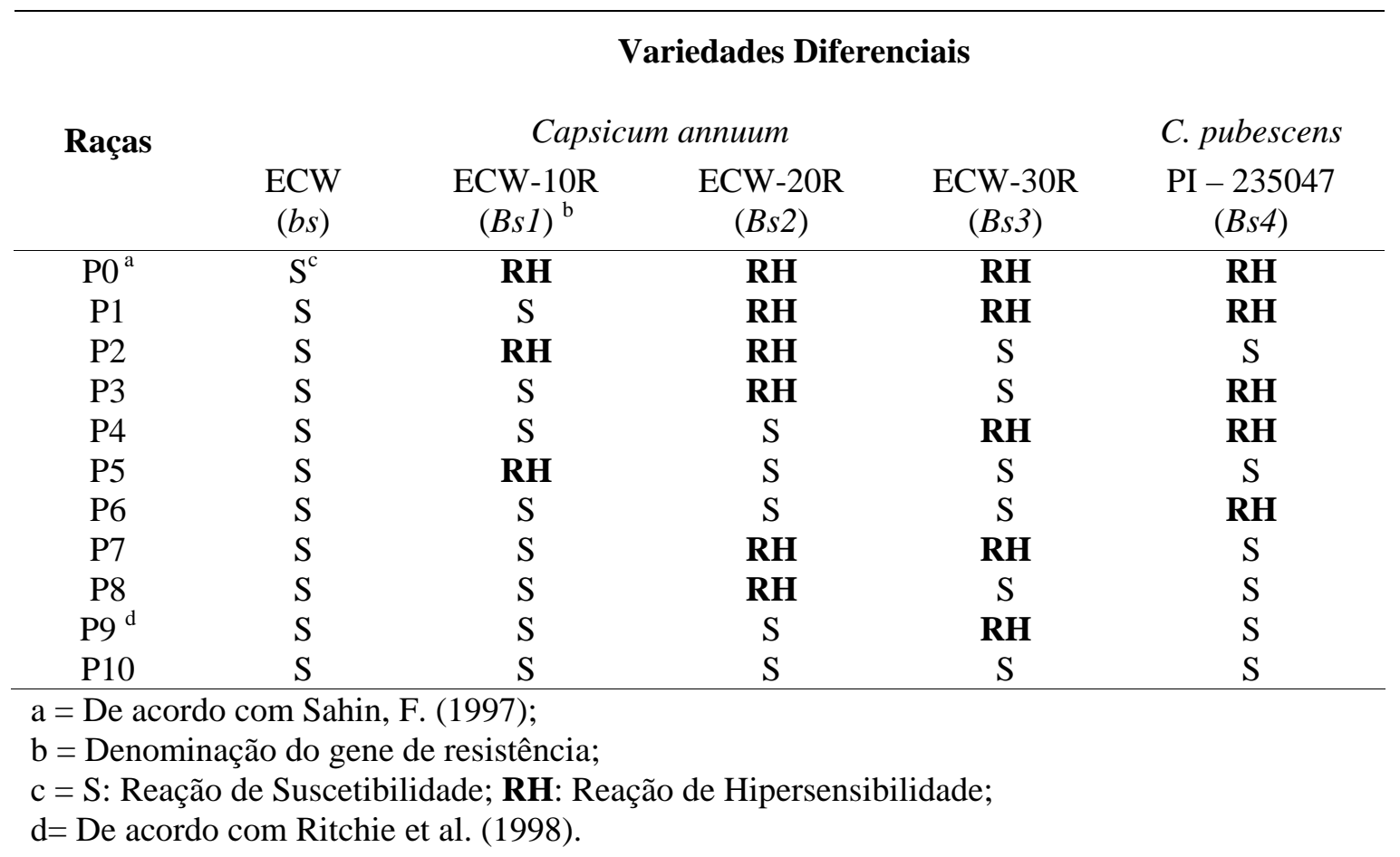




\subsection{Experimentos para a determinação de raças fisiológicas de Xanthomonas spp., baseados em inoculação nos genótipos diferenciais}

Todos os experimentos foram conduzidos sobre bancadas de tela de aço, em casas de vegetação de policarbonato, com controle parcial de temperatura e com sistema de nebulização, na Estação Experimental de Sakata Seed Sudamerica, situada no município de Bragança Paulista, Estado de São Paulo, Brasil.

Devido ao número de isolados e à limitação da estrutura necessária disponível, optou-se por dividir o trabalho em 3 experimentos (A, B e C); porém, foram utilizados isolados padrões em cada experimento realizado.

\subsubsection{Origem e número dos isolados de Xanthomonas spp. obtidos}

Nos Experimentos foram avaliados isolados de diferentes regiões produtoras de pimentão do Estado de São Paulo, conforme mostra a Tabela 6.

Tabela 6. Origem e número de isolados dos Experimentos A, B e C

\begin{tabular}{|c|c|c|c|}
\hline Experimento & Origem dos isolados & $\begin{array}{c}\mathrm{N}^{\mathrm{o}} \text { de isolados / } \\
\text { região }\end{array}$ & $\begin{array}{c}\mathbf{N}^{\circ} \text { de isolados / } \\
\text { Experimento }\end{array}$ \\
\hline \multirow{3}{*}{ Experimento A } & Piedade & 06 & \multirow{3}{*}{14} \\
\hline & Bragança Paulista & 04 & \\
\hline & Bacuriti & 04 & \\
\hline \multirow{2}{*}{ Experimento B } & Lins & 11 & \multirow{2}{*}{14} \\
\hline & Ibiúna & 03 & \\
\hline \multirow{3}{*}{ Experimento C } & Piacatu & 01 & \multirow{3}{*}{13} \\
\hline & Mogi das Cruzes & 11 & \\
\hline & Guaíra & 01 & \\
\hline
\end{tabular}




\subsubsection{Obtenção das plantas dos genótipos diferenciais}

As plantas foram obtidas a partir de sementes tratadas com hipoclorito de sódio a 0,25\% (produto comercial 2,5\% diluído na proporção 1:9/v:v). A semeadura (3 sementes/célula), foi realizada em bandejas de isopor contendo substrato agrícola Eucatex, e as plantas foram mantidas em casa de vegetação. O transplante (3 plantas/vaso), foi realizado para vasos plásticos contendo solo autoclavado, com capacidade para 1,2 litros de solo, aproximadamente 25 dias após a semeadura, no estádio de emissão do primeiro par de folhas verdadeiras. Para o preparo do solo foram utilizados 4 sacos de vermiculita média Plantmax, 7 sacos de substrato e o volume

completado para 1 metro cúbico $\left(1 \mathrm{~m}^{3}\right)$ com solo de sub-solo. Adicionaram-se $5 \mathrm{~kg}$ de calcáreo - Minercal agrícola, 3 kg de termofosfato magnesiano - Yoorin Master-BZ e 12 kg de adubo (4-14-8).

As plantas foram mantidas, desde a semeadura até a inoculação em casa de vegetação, com variação de temperatura entre $24^{\circ} \mathrm{C}$ e $30^{\circ} \mathrm{C}$.

\subsubsection{Preparo do inóculo e inoculação dos genótipos diferenciais com Xanthomonas spp.}

Após a repicagem e a incubação dos isolados para placas de Petri contendo NA (peptona - dextrose - ágar), por um período de 48 h., os isolados foram repicados para erlenmeyers contendo Nutriente Líquido - NL (Peptona - 5 g e Extrato de Carne - 3 g por litro de água) e incubados por mais $48 \mathrm{~h}$ em uma estufa bacteriológica, à temperatura de $28^{\circ} \mathrm{C}$. A suspensão obtida nestas condições, apresentava, de acordo com a literatura, a 
concentração em fase logarítmica de crescimento. A densidade de células, foi ajustada em espectrofotômetro calibrado a O. D. $6 \mathrm{~nm}$, onde utilizou-se para Xanthomonas a leitura de O.D. 0,3 nm, a qual equivale a 3 X $10^{8} \mathrm{UFCs} / \mathrm{ml}$. O ajuste do inóculo foi feito diluindo-se esta suspensão à 1:9 (v:v), obtendo-se assim, uma concentração de 3 X $10^{7}$ UFCs / ml. No inóculo final foram adicionadas 3 gotas de Tween 20 por litro.

A inoculação foi realizada em estádio fenológico correspondente ao $3^{\circ}$ e o $4^{\circ}$ par de folhas verdadeiras. As plantas foram submetidas à câmara úmida durante as $24 \mathrm{~h}$ antecedentes à inoculação. A inoculação foi feita pulverizando-se a suspensão bacteriana ajustada à concentração de $3 \times 10^{7} \mathrm{ufc} / \mathrm{ml}$ na página inferior das folhas e em seguida também na página superior (Figura 4A). Após a inoculação, as plantas foram mantidas em câmara úmida por mais 48 h (Figura 4B). Após a etapa de câmara úmida, as plantas foram nebulizadas por um período de 72 a $96 \mathrm{~h}$.

Os experimentos com plantas foram mantidos desde a inoculação até a avaliação em casa de vegetação, com variação de temperatura entre $24^{\circ} \mathrm{C}$ e $30^{\circ} \mathrm{C}$.
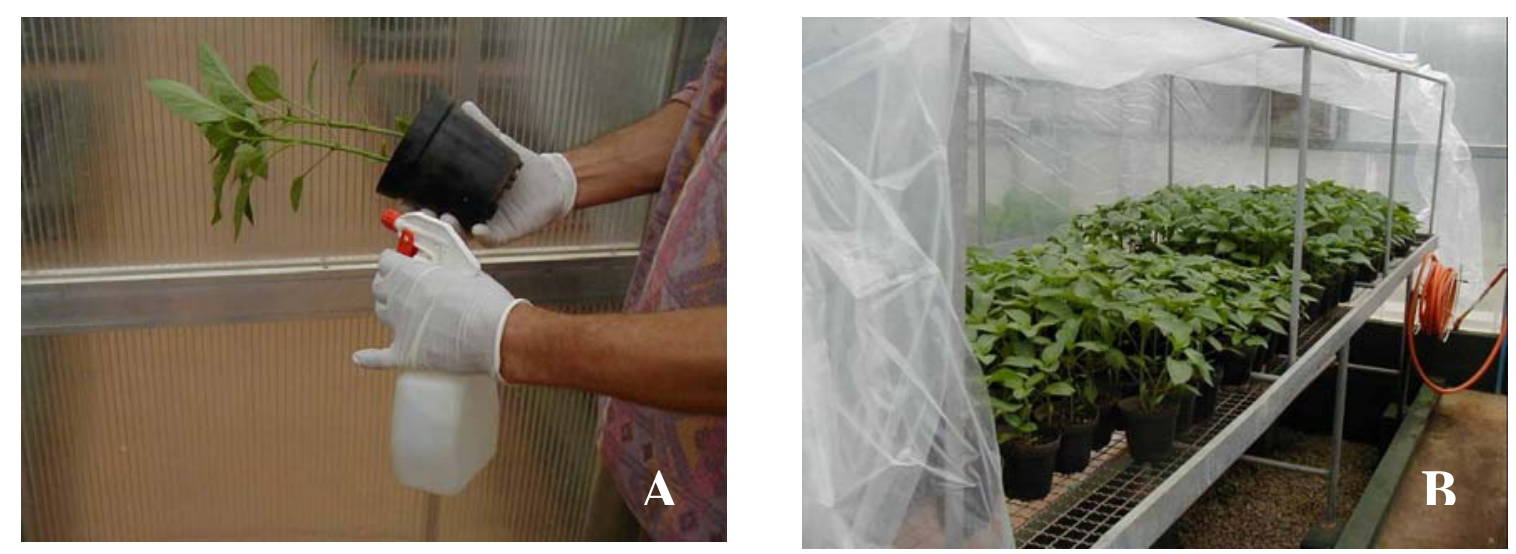

Figura 4 - A, inoculação por aspersão das mudas de pimentão. B, câmara úmida 


\subsubsection{Avaliação dos sintomas de Xanthomonas spp. na série diferencial}

A avaliação foi realizada 8 a 10 dias após a inoculação. Foram avaliados os sintomas de suscetibilidade (compatibilidade) e de resistência / hipersensibilidade (incompatibilidade), nos genótipos diferenciais de pimentão. Em cada experimento foram incluídos: o isolado CL.445 (Clínica SDA - proveniente de Lins/SP), pertencente à raça 1, e o isolado P. 3177 (Botucatu), pertencente à raça 2, como isolados testemunhas. No dia seguinte à avaliação todos os isolados foram recuperados para armazenamento.

\subsection{Método comparativo da avaliação de similaridade entre os isolados de Xanthomonas spp.}

Para auxiliar a interpretação dos dados gerados a partir da reação das plantas dos genótipos diferenciais à inoculação com Xanthomonas spp., foi adotada uma técnica de agrupamento dos dados baseada na avaliação da similaridade entre os indivíduos/ isolados, que permitisse a comparação entre os isolados, e a isolados padrões.

O desenho experimental realizado foi o de 3 repetições de 6 plantas por isolado a ser identificado, e o delineamento foi o de blocos ao acaso. 


\subsubsection{Matriz de valores binários}

Para que se estabelecessem dados comparativos para a avaliação de similaridade entre os isolados, foi necessária a obtenção de uma matriz binária com os dados de todos os isolados a serem identificados.

O emprego da técnica de identificação da presença ou ausência de uma determinada característica fornece esta matriz de valores binários em que as linhas dessa matriz representam os diferentes genótipos e as colunas representam as diferentes características a serem comparadas.

\subsubsection{Obtenção da Matriz de Valores Binários}

Dunn \& Everitt (1980) designaram por zeros e uns os estados do caráter para caracteres binários, que poderão ser submetidos posteriormente à análise. Como definido por estes autores, o número 1 indica a presença da característica e 0 , a ausência. Genótipos que possuam maior coincidência de presenças e/ou ausências das características, serão considerados mais similares entre si.

Os dados obtidos com o emprego da técnica de identificação dos genes de resistência através da observação da reação de hipersensibilidade $(\mathrm{RH})$, forneceram uma matriz de distâncias de valores binários/ binária (hipersensibilidade x suscetibilidade) (Tabela 7), em que as linhas dessa matriz representam os diferentes genótipos e as colunas representam as diferentes características a serem comparadas. Neste caso, cada linha corresponde à identificação de um isolado, e as colunas à reação de hipersensibilidade e suscetibilidade, determinada pela reação de uma variedade 
diferencial a uma raça previamente conhecida. A reação de hipersensibilidade $(\mathrm{RH})$ é identificada pelo número 1 enquanto a de suscetibilidade (S), por 0 .

Tabela 7. Matriz Binária considerando-se 5 linhagens e 11 isolados caracterizados.

\begin{tabular}{|c|c|c|c|c|c|c|}
\hline \multirow[b]{2}{*}{ Isolado } & \multicolumn{5}{|c|}{ Variedades Diferenciais ${ }^{1}$} & \multirow[b]{2}{*}{ Identificação } \\
\hline & $\begin{array}{c}\text { ECW } \\
(b s)\end{array}$ & $\begin{array}{c}\text { ECW-10R } \\
(B s 1)^{2}\end{array}$ & $\begin{array}{c}\text { ECW-20R } \\
(B s 2)\end{array}$ & $\begin{array}{c}\text { ECW-30R } \\
(\text { Bs3) }\end{array}$ & $\begin{array}{c}\text { PI-235047 } \\
\text { (Bs4) }\end{array}$ & \\
\hline $\mathrm{PO}^{3}$ & 0 & $1^{4}$ & 1 & 1 & 1 & Raça 0 \\
\hline $\mathrm{P} 1$ & 0 & 0 & 1 & 1 & 1 & Raça 1 \\
\hline $\mathrm{P} 2$ & 0 & 1 & 1 & 0 & 0 & Raça 2 \\
\hline P3 & 0 & 0 & 1 & 0 & 1 & Raça 3 \\
\hline $\mathrm{P} 4$ & 0 & 0 & 0 & 1 & 1 & Raça 4 \\
\hline P5 & 0 & 1 & 0 & 0 & 0 & Raça 5 \\
\hline P6 & 0 & 0 & 0 & 0 & 1 & Raça 6 \\
\hline P7 & 0 & 0 & 1 & 1 & 0 & Raça 7 \\
\hline P8 & 0 & 0 & 1 & 0 & 0 & Raça 8 \\
\hline P9 & 0 & 0 & 0 & 1 & 0 & Raça 9 \\
\hline $\mathrm{P} 10$ & 0 & 0 & 0 & 0 & 0 & Raça 10 \\
\hline
\end{tabular}

$1=$ De acordo com Hibberd (1987);

2 = Denominação do gene de resistência;

3 = P0 a P10 - Reações de raças conhecidas;

4 = 1: Presença de RH; 0: Ausência de RH.

De acordo com a matriz de dados padronizados obtida para todos os isolados, foi escolhida uma medida que quantificasse o nível de similaridade entre os isolados, ou seja, o quanto dois indivíduos são parecidos. Os coeficientes de similaridade obtidos a partir dos dados gerados pela matriz de valores binários (Tabela 7), geraram a matriz de similaridades. 


\subsubsection{Obtenção da Matriz de Similaridades}

Quando dois genótipos são comparados podem ocorrer as seguintes situações, para cada característica: i) ambos possuem a mesma característica, ou seja, valor 1 (código 1 e 1); ii) um genótipo possui a característica e o outro não (código 1 e 0 , ou 0 e 1); iii) ambos não possuem tal característica (código 0 e 0).

Tais coeficientes podem ser divididos em duas categorias: medidas de similaridade e medidas de dissimilaridade. Para a primeira categoria, quanto maior o valor observado, mais parecidos são os indivíduos; para a segunda, quanto maior o valor observado menos parecidos são os indivíduos.

Conforme proposto por Carlini-Garcia (1998), para cada par de genótipos (i, $j$ ) estudado, as medidas de similaridade/ dissimilaridade para caracteres binários, baseiamse em tabelas 2x2, de acordo como apresentado no Tabela 8.

Tabela 8. Quantificação da similaridade/ dissimilaridade entre os genótipos $i$ e $j$

\begin{tabular}{|c|c|c|c|c|}
\hline \multirow{5}{*}{ ن } & & \multicolumn{2}{|c|}{ Genótipo i } & \\
\hline & & 1 & 0 & \\
\hline & 1 & $\mathrm{a}$ & $\mathrm{b}$ & $a+b$ \\
\hline & 0 & c & $\mathrm{d}$ & $c+d$ \\
\hline & & $a+c$ & $b+d$ & $a+b+c+d$ \\
\hline
\end{tabular}

Nessa situação, $a$ é o número de características para as quais ambos os genótipos apresentaram código 1 (presença), $b$ é o número de códigos 0 para o genótipo $i$ e 1 para 
o genótipo $j$, $c$ é o número de códigos 1 para o genótipo $i$ e 0 para o genótipo $j, d$ é o número de vezes para os quais ambos genótipos tiveram código 0 (ausência), $a+b+c+d$ é o número total de caracteres (ou marcas) binários estudados. O número de coincidências é representado por $a+d$ e o número de diferenças é representado por $b+$ c (Dunn \& Everitt, 1980). Os coeficientes de similaridade para dados binários, baseiamse na comparação entre o número de atributos comuns para um par de objetos e o número total de atributos envolvidos. Os coeficientes de similaridades podem ser divididos em dois grupos: os que consideram ausência conjunta e os que não consideram a ausência conjunta (Carlini-Garcia, 1998). Entre os coeficientes que desconsideram a ausência conjunta está o coeficiente de Jaccard (1908), que compara o número de presenças de marcas / atributos comuns e o número total de marcas / atributos envolvidos, excluindo o número de ausências conjuntas. A fórmula descrita para obtenção deste coeficiente está apresentada no Tabela 9.

Tabela 9. Coeficiente de similaridade de Jaccard

\begin{tabular}{ccc}
\hline Coeficientes & Fórmula $*$ & Intervalo de Ocorrência \\
\hline Jaccard & $a /(a+b+c)$ & {$[0,1]$} \\
\hline
\end{tabular}

Considerando-se o aspecto de que os coeficientes de similaridade para dados binários são a comparação entre o número de características comuns e o número total de características envolvidas, foi escolhido o Coeficiente de Jaccard (Jaccard, 1908). Desta forma, utilizando-se a tabela para quantificação da similaridade (Tabela 8) classificaramse nas linhas $(j)$ as reações $(0,1)$ dos isolados a serem identificados e, nas colunas (i) a reação dos isolados conhecidos para efeito comparativo. A comparação dos isolados foi realizada aos pares, comparando-se cada isolado avaliado aos isolados conhecidos, desconsiderando a ausência conjunta, conforme estabelece o Coeficiente de Jaccard. 


\section{RESULTADOS E DISCUSSÃO}

\subsection{Identificação dos isolados de Xanthomonas spp.}

Todos os 41 isolados obtidos, comportaram-se como Gram-negativos, apresentaram reação positiva nos testes de patogenicidade em pimentão e apresentaram coloração amarela em crescimento em meio semi-seletivo YDC e em meio de NA. Foram observadas contaminações com Clavibacter michiganensis subsp. michiganensis em meio de NA em algumas amostras, porém, os trabalhos de repicagens subseqüentes permitiram a obtenção de culturas puras de Xanthomonas spp..

Portanto, o comportamento dos isolados nos procedimentos de isolamento indicou viscosidade de todos os isolados no teste de Ryce, apresentando reação positiva para Gram-negativos (Suslow et al., 1982). De acordo com Schaad (2001), o crescimento amarelo em NA e no meio semi-seletivo YDC, de todos os isolados, também foi importante na determinação do gênero Xanthomonas nos procedimentos de isolamento.

As informações obtidas em literatura sobre: o contato íntimo bactéria x célula, proposto por Stall \& Cook (1979); o pré-condicionamento para a abertura dos estômatos, proposto por Mariano (2000); a utilização da técnica de inoculação por aspersão, já utilizada por Kobori \& Wierzbicki (2000); o período de incubação, havendo relatos de 
até 03 dias de câmara úmida para o método da imersão de mudas (Kousik \& Ritchie, 1999; Romero et al., 2002), sendo que de acordo com Mariano (2000), a câmara úmida pode ser de 24 h para o método de aspersão; e ainda os relatos sobre "quebra de resistência” do gene Bs2 a 32 graus (Romero et al., 2002); permitiram um melhor balizamento dos experimentos de modo que não ocorreram reações inesperadas em relação a estas técnicas utilizadas.

A avaliação foi realizada de 07 a 10 dias após a inoculação, o que está de acordo com a Sahin \& Miller (1996); Mariano (2000), que relatam 07 dias após a inoculação. A diferenciação entre o tipo de lesão causada pela RH e a lesão causada por suscetibilidade foi visível, permitindo a distinção das reações, conforme mostra a Figura 5.

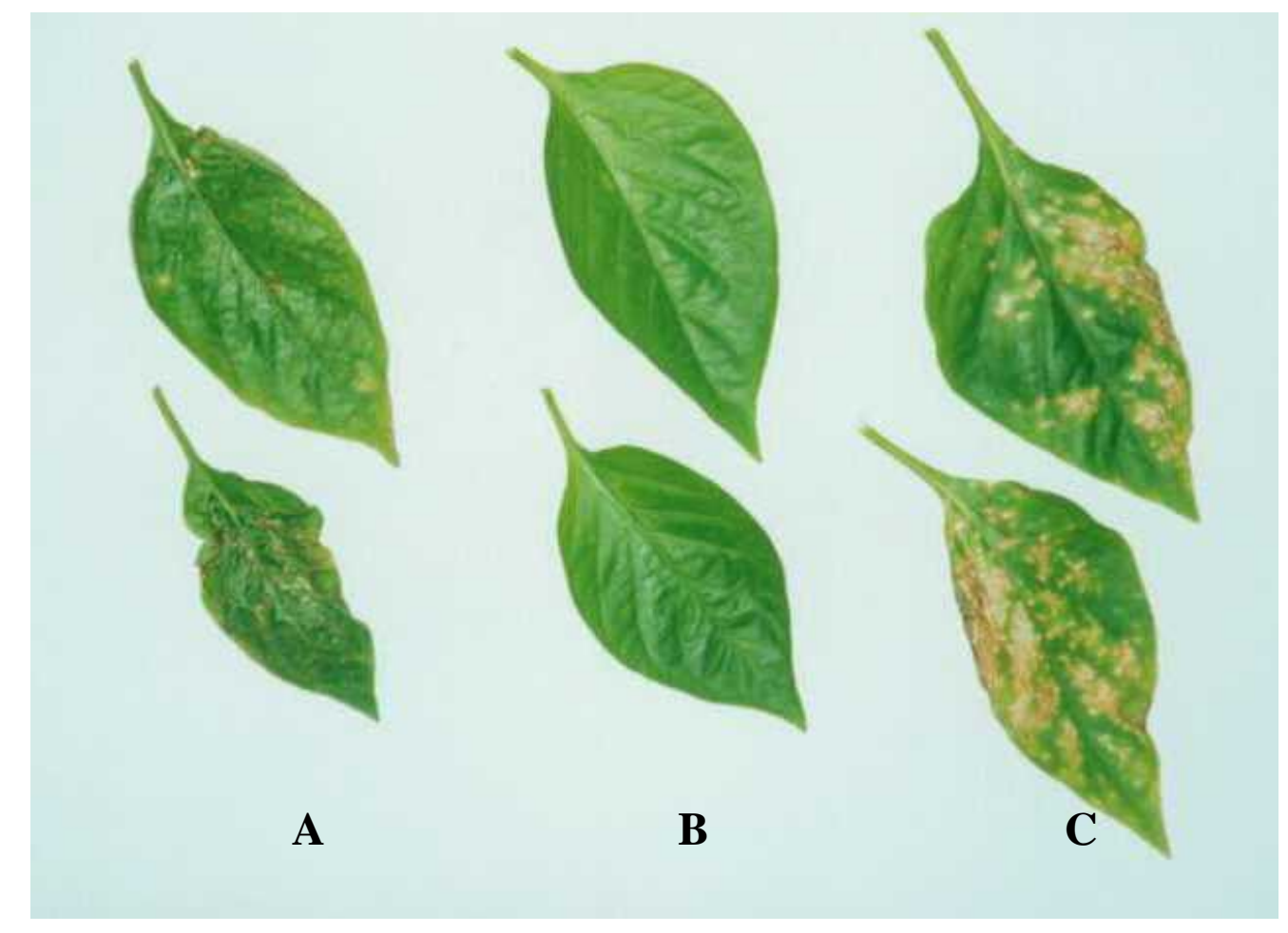

Figura 5 - Reações de folhas de pimentão a Xanthomonas spp.: A, reação de RH; B, não inoculado; C, reação de susceptibilidade 
Sendo uma reação bioquímica induzida, a RH é uma reação qualitativa ligada à presença do gene de avirulência do patógeno, determinando a ocorrência da RH desde que o gene de hipersensibilidade correspondente do hospedeiro esteja presente. Desta forma a presença de 01 ou 10 lesões de hipersensibilidade sobre a folha, indicaram a presença do gene de avirulência do patógeno. As reações de suscetibilidade tenderam a aumentar em tamanho, aumentando a área lesionada e coalescer, já as reações de hipersensibilidade não tenderam a aumentar, e conforme o crescimento/ desenvolvimento da folha foram "empurradas” para os bordos foliares, pelo método de inoculação por aspersão utilizado.

\subsection{Experimentos para identificação de raças fisiológicas de Xanthomonas spp. baseados em inoculação nos genótipos diferenciais}

As reações nos genótipos diferenciais utilizados permitiram a clara observação das reações de suscetibilidade e resistência, sendo esta última reação caracterizada por reação de hipersensibilidade $(\mathrm{RH})$.

Além da comparação dos isolados por medidas de similaridade entre isolados, e da comparação com a reação de isolados testemunhas, as reações de resistência ou suscetibilidade $(\mathrm{R} / \mathrm{S})$ dos 41 isolados aos genótipos diferenciais foram comparadas às reações de 11 isolados caracterizados (raças 0 à 10) nas mesmas 5 diferenciais, descritas na Tabela 5, ítem 3.3. A reação de resistência aqui descrita, corresponde à reação de RH naquela tabela, por se tratar do tipo de resistência hipersensível.

A identificação ou não da reação de hipersensibilidade geraram variáveis qualitativas binárias, caracterizadas pela incidência (presença ou ausência) de RH (a 
presença da RH codificada como 1 e a ausência como 0 - Tabela 7, ítem 3.5.2) para cada isolado avaliado.

A técnica de agrupamento dos dados dos Experimento A, B e C permitiu a comparação dos isolados, de acordo com o Coeficiente de Similaridade de Jaccard. O agrupamento dos dados, foi realizado pela comparação entre dois isolados de cada vez, de forma que cada isolado a ser identificado, fosse comparado com um isolado conhecido, até que o mesmo fosse comparado a todos os isolados conhecidos (Exp. A Tabela 10; Exp. B - Tabela 12 e Exp. C - Tabela 14). Os valores, foram compostos da seguinte forma, nas matrizes de similaridade: $\mathrm{a}$ / $\mathrm{a}+\mathrm{b}+\mathrm{c}$, onde: $\mathrm{a}=\mathrm{n}^{0}$ de vezes em que coincide a presença de HR (1) no isolado conhecido e no isolado a ser identificado; b = $\mathrm{n}^{0}$ de vezes em que há ausência de HR (0) no isolado conhecido e, presença (1) no isolado a ser identificado; $c=n^{0}$ de vezes em que há presença de HR (1) no isolado conhecido e, ausência (0) no isolado a ser identificado.

Desta forma, as medidas de similaridade indicaram que quanto maior o valor observado, mais parecidos foram os indivíduos; então, genótipos que possuíam maiores coincidências de presenças das características foram considerados similares entre si. Além disso, as reações de todos os isolados foram comparadas às reações conhecidas dos 2 isolados padrões P-3177 (raça 2) e Cl. 445 (raça 1).

Com base nestes resultados, foi possível definir-se claramente a qual raça já conhecida estes isolados pertenciam. Então, as reações de 14 isolados avaliados, provenientes de Piedade, Bragança Paulista e Bacuriti - Experimento A (Tabela 11); 14 isolados provenientes de Lins e Ibiúna - Experimento B (Tabela 13) e 13 isolados provenientes de Mogi das Cruzes, Guaíra e Piacatu - Experimento C (Tabela 15) foram interpretadas e assim representadas em raças. As tabelas dos experimentos, são apresentadas no final desse item.

De acordo com os resultados foram observadas as seguintes raças por experimento: no Experimento A: Piedade - raças 3 e 8, Bragança Paulista - raças 2 e 8 
e Bacuriti - raças 1 e 2; no Experimento B: Lins - raças 0, 2 e 8, Ibiúna - raça 2; no Experimento C: Piacatu - raça 2, Mogi das Cruzes - raças 7 e 8 e Guaíra - raça 2. 
Tabela 10. Experimento A - Matrizes de Similaridade obtidas a partir de 11 raças conhecidas e 14 isolados rovenientes das regiões de Piedade, Bragança Paulista e Bacuriti

\begin{tabular}{|c|c|c|c|c|c|c|c|c|c|c|c|c|}
\hline \multicolumn{13}{|c|}{ Reação das Raças } \\
\hline Isolados & P0 & P1 & $\mathbf{P 2}$ & P3 & $\mathbf{P 4}$ & P5 & P6 & P7 & P8 & P9 & P10 & Obs. \\
\hline PI-440 & $0,50^{\mathrm{a}}$ & 0,25 & $1,00^{b}$ & 0,33 & 0,00 & 0,50 & 0,00 & 0,33 & 0,50 & 0,00 & 0,00 & Raça 2 \\
\hline PI-352 & 0,50 & 0,25 & 1,00 & 0,33 & 0,00 & 0,50 & 0,00 & 0,33 & 0,50 & 0,00 & 0,00 & Raça 2 \\
\hline PI-394 & 0,25 & 0,33 & 0,50 & 0,50 & 0,00 & 0,00 & 0,00 & 0,50 & 1,00 & 0,00 & 0,00 & Raça 8 \\
\hline PI-335 & 0,75 & 1,00 & 0,25 & 0,66 & 0,66 & 0,00 & 0,33 & 0,66 & 0,33 & 0,33 & 0,00 & Raça 1 \\
\hline PI-337 & 0,75 & 1,00 & 0,25 & 0,66 & 0,66 & 0,00 & 0,33 & 0,66 & 0,33 & 0,33 & 0,00 & Raça 1 \\
\hline PI-254 & 0,25 & 0,33 & 0,50 & 0,50 & 0,00 & 0,00 & 0,00 & 0,50 & 1,00 & 0,00 & 0,00 & Raça 8 \\
\hline PI-599 & 0,25 & 0,33 & 0,50 & 0,50 & 0,00 & 0,00 & 0,00 & 0,50 & 1,00 & 0,00 & 0,00 & Raça 8 \\
\hline PI-582 & 0,25 & 0,33 & 0,50 & 0,50 & 0,00 & 0,00 & 0,00 & 0,50 & 1,00 & 0,00 & 0,00 & Raça 8 \\
\hline PI-593-1 & 0,25 & 0,33 & 0,50 & 0,50 & 0,00 & 0,00 & 0,00 & 0,50 & 1,00 & 0,00 & 0,00 & Raça 8 \\
\hline PI-593-3 & 0,25 & 0,33 & 0,50 & 0,50 & 0,00 & 0,00 & 0,00 & 0,50 & 1,00 & 0,00 & 0,00 & Raça 8 \\
\hline PI-593-2 & 0,25 & 0,33 & 0,50 & 0,50 & 0,00 & 0,00 & 0,00 & 0,50 & 1,00 & 0,00 & 0,00 & Raça 8 \\
\hline PI-593-4 & 0,25 & 0,33 & 0,50 & 0,50 & 0,00 & 0,00 & 0,00 & 0,50 & 1,00 & 0,00 & 0,00 & Raça 8 \\
\hline PI-593-5 & 0,25 & 0,33 & 0,50 & 0,50 & 0,00 & 0,00 & 0,00 & 0,50 & 1,00 & 0,00 & 0,00 & Raça 8 \\
\hline PI-593-6 & 0,50 & 0,66 & 0,33 & 1,00 & 0,33 & 0,00 & 0,50 & 0,33 & 0,50 & 0,00 & 0,00 & Raça 3 \\
\hline P-3177 & 0,50 & 0,25 & 1,00 & 0,33 & 0,00 & 0,50 & 0,00 & 0,33 & 0,50 & 0,00 & 0,00 & Test. Raça 2 \\
\hline Cl. 445 & 0,75 & 1,00 & 0,25 & 0,66 & 0,66 & 0,00 & 0,33 & 0,66 & 0,33 & 0,33 & 0,00 & Test. Raça 1 \\
\hline
\end{tabular}

a- Cálculo obtido pela Fórmula de Jaccard: $a /(a+b+c)$

b- $\mathrm{O}$ valor 1,00 indica relação com a raça respectiva 
Tabela 11. Experimento A - Caracterização das raças fisiológicas de Xanthomonas spp. conforme a reação de 14 isolados provenientes de Piedade, Bragança Paulista e Bacuriti, em 05 genótipos diferenciais

\begin{tabular}{|c|c|c|c|c|c|c|c|}
\hline \multirow[b]{2}{*}{ Isolado } & \multirow[b]{2}{*}{ Origem } & \multicolumn{5}{|c|}{ Genótipos Diferenciais $^{1}$} & \multirow[b]{2}{*}{ Resultado } \\
\hline & & $\begin{array}{c}\text { ECW } \\
\text { (bs) }\end{array}$ & $\begin{array}{c}\text { ECW-10R } \\
(\text { Bs1) }\end{array}$ & $\begin{array}{c}\text { ECW-20R } \\
(\text { Bs2) }\end{array}$ & $\begin{array}{c}\text { ECW-30R } \\
\text { (Bs3) }\end{array}$ & $\begin{array}{c}\text { PI-235047 } \\
\text { (Bs4) }\end{array}$ & \\
\hline PI-440 & $\begin{array}{c}\text { Bragança } \\
\text { Paulista }\end{array}$ & $\mathrm{S}$ & $\mathrm{R}^{1 / 3}$ & $\mathrm{R}$ & $\mathrm{S}$ & $\mathrm{S}$ & Raça 2 \\
\hline PI-352 & Bacuriti & S & $\mathrm{R}$ & $\mathrm{R}$ & S & S & Raça 2 \\
\hline PI-394 & $\begin{array}{l}\text { Bragança } \\
\text { Paulista }\end{array}$ & S & $\mathrm{S}$ & $\mathrm{R}$ & S & $S$ & Raça 8 \\
\hline PI-335 & Bacuriti & S & $S$ & $\mathrm{R}$ & $\mathrm{R}$ & $\mathrm{R}$ & Raça 1 \\
\hline PI-337 & Bacuriti & $S$ & $S$ & $\mathrm{R}$ & $\mathrm{R}$ & $\mathrm{R}$ & Raça 1 \\
\hline PI-254 & $\begin{array}{l}\text { Bragança } \\
\text { Paulista }\end{array}$ & $\mathrm{S}$ & $S$ & $\mathrm{R}$ & S & $S$ & Raça 8 \\
\hline PI-582 & Bacuriti & $\mathrm{S}$ & S & $\mathrm{R}$ & S & S & Raça 8 \\
\hline PI-599 & $\begin{array}{l}\text { Bragança } \\
\text { Paulista }\end{array}$ & $\mathrm{S}$ & S & $\mathrm{R}$ & S & S & Raça 8 \\
\hline PI-593-1 & Piedade & S & S & $\mathrm{R}$ & S & S & Raça 8 \\
\hline PI-593-3 & Piedade & S & S & $\mathrm{R}$ & S & S & Raça 8 \\
\hline PI-593-2 & Piedade & $S$ & S & $\mathrm{R}$ & $S$ & S & Raça 8 \\
\hline PI-593-4 & Piedade & S & $S$ & $\mathrm{R}$ & $S$ & $S$ & Raça 8 \\
\hline PI-593-5 & Piedade & $S$ & $S$ & $\mathrm{R}$ & $S$ & $S$ & Raça 8 \\
\hline PI-593-6 & Piedade & S & $\mathrm{S}$ & $\mathrm{R}$ & S & $\mathrm{R}$ & Raça 3 \\
\hline P-3177 & Botucatu & S & $\mathbf{R}$ & $\mathbf{R}$ & $\mathbf{S}$ & $\mathbf{S}$ & Testemunha - Raça 2 \\
\hline Cl. 445 & SDA - Lins & $\mathbf{S}$ & $\mathbf{S}$ & $\mathbf{R}$ & $\mathbf{R}$ & $\mathbf{R}$ & Testemunha - Raça 1 \\
\hline
\end{tabular}

$1 /$ = De acordo com Hibberd, 1987;

2/ = Denominação do gene de resistência;

3/ = S: Reação de Suscetibilidade; R: Reação de Resistência;

P.S. Reações avaliadas conforme a média obtida de 03 repetições de 06 plantas. 
Tabela 12. Experimento B - Matrizes de Similaridade obtidas a partir de 11 raças conhecidas e 14 isolados provenientes das regiões de Lins e Ibiúna

\begin{tabular}{|c|c|c|c|c|c|c|c|c|c|c|c|c|}
\hline \multirow[b]{2}{*}{ Isolados } & \multirow[b]{2}{*}{ P0 } & \multirow[b]{2}{*}{$\mathbf{P 1}$} & \multirow[b]{2}{*}{$\mathbf{P 2}$} & \multirow[b]{2}{*}{ P3 } & \multicolumn{3}{|c|}{ Reação das Raças } & \multirow[b]{2}{*}{ P7 } & \multirow[b]{2}{*}{ P8 } & \multirow[b]{2}{*}{ P9 } & \multirow[b]{2}{*}{ P10 } & \multirow[b]{2}{*}{ Obs. } \\
\hline & & & & & P4 & P5 & P6 & & & & & \\
\hline PI-166 & $0,50^{\mathrm{a}}$ & 0,25 & $1,00^{b}$ & 0,33 & 0,00 & 0,50 & 0,00 & 0,33 & 0,50 & 0,00 & 0,00 & Raça 2 \\
\hline PI-287 & 0,50 & 0,25 & 1,00 & 0,33 & 0,00 & 0,50 & 0,00 & 0,33 & 0,50 & 0,00 & 0,00 & Raça 2 \\
\hline PI-500 & 0,50 & 0,25 & 1,00 & 0,33 & 0,00 & 0,50 & 0,00 & 0,33 & 0,50 & 0,00 & 0,00 & Raça 2 \\
\hline PI-495 & 0,25 & 0,33 & 0,50 & 0,50 & 0,00 & 0,00 & 0,00 & 0,50 & 1,00 & 0,00 & 0,00 & Raça 8 \\
\hline PI-502 & 1,00 & 0,75 & 0,50 & 0,50 & 0,50 & 0,25 & 0,25 & 0,50 & 0,25 & 0,25 & 0,00 & Raça 0 \\
\hline PI-501 & 0,50 & 0,25 & 1,00 & 0,33 & 0,00 & 0,50 & 0,00 & 0,33 & 0,50 & 0,00 & 0,00 & Raça 2 \\
\hline PI-504 & 0,25 & 0,33 & 0,50 & 0,50 & 0,00 & 0,00 & 0,00 & 0,50 & 1,00 & 0,00 & 0,00 & Raça 8 \\
\hline PI-592-2 & 0,50 & 0,25 & 1,00 & 0,33 & 0,00 & 0,50 & 0,00 & 0,33 & 0,50 & 0,00 & 0,00 & Raça 2 \\
\hline PI-592-1 & 0,50 & 0,25 & 1,00 & 0,33 & 0,00 & 0,50 & 0,00 & 0,33 & 0,50 & 0,00 & 0,00 & Raça 2 \\
\hline PI-592-4 & 0,50 & 0,25 & 1,00 & 0,33 & 0,00 & 0,50 & 0,00 & 0,33 & 0,50 & 0,00 & 0,00 & Raça 2 \\
\hline PI-683 & 0,50 & 0,25 & 1,00 & 0,33 & 0,00 & 0,50 & 0,00 & 0,33 & 0,50 & 0,00 & 0,00 & Raça 2 \\
\hline PI-684 & 0,50 & 0,25 & 1,00 & 0,33 & 0,00 & 0,50 & 0,00 & 0,33 & 0,50 & 0,00 & 0,00 & Raça 2 \\
\hline PI-685 & 0,50 & 0,25 & 1,00 & 0,33 & 0,00 & 0,50 & 0,00 & 0,33 & 0,50 & 0,00 & 0,00 & Raça 2 \\
\hline PI-686 & 0,50 & 0,25 & 1,00 & 0,33 & 0,00 & 0,50 & 0,00 & 0,33 & 0,50 & 0,00 & 0,00 & Raça 2 \\
\hline P-3177 & 0,50 & 0,25 & 1,00 & 0,33 & 0,00 & 0,50 & 0,00 & 0,33 & 0,50 & 0,00 & 0,00 & Test. Raça 2 \\
\hline Cl. 445 & 0,75 & 1,00 & 0,25 & 0,66 & 0,66 & 0,00 & 0,33 & 0,66 & 0,33 & 0,33 & 0,00 & Test. Raça 1 \\
\hline
\end{tabular}

a- Cálculo obtido da comparação 2 a 2 pela Fórmula de Jaccard: $a$ / $(a+b+c)$

b- $O$ valor 1,00 indica relação com a raça respectiva. 
Tabela 13. Experimento B - Caracterização das raças fisiológicas de Xanthomonas spp. conforme a reação de 14 isolados provenientes de Lins e Ibiúna, em 5 genótipos diferenciais

\begin{tabular}{|c|c|c|c|c|c|c|c|}
\hline \multicolumn{8}{|c|}{ Genótipos Diferenciais ${ }^{1}$} \\
\hline Isolado & Origem & $\begin{array}{c}\text { ECW } \\
\text { (bs) }\end{array}$ & $\begin{array}{c}\text { ECW-10R } \\
(B s 1)^{/ 2}\end{array}$ & $\begin{array}{c}\text { ECW-20R } \\
\text { (Bs2) }\end{array}$ & $\begin{array}{c}\text { ECW-30R } \\
\text { (Bs3) }\end{array}$ & $\begin{array}{c}\text { PI-235047 } \\
\text { (Bs4) }\end{array}$ & Resultado \\
\hline PI-166 & Lins & $\mathrm{S}$ & $\mathrm{R}^{1 / 3}$ & $\mathrm{R}$ & $\mathrm{S}$ & $\mathrm{S}$ & Raça 2 \\
\hline PI-287 & Lins & S & $\mathrm{R}$ & $\mathrm{R}$ & S & S & Raça 2 \\
\hline PI-500 & Lins & S & $\mathrm{R}$ & $\mathrm{R}$ & S & S & Raça 2 \\
\hline PI-495 & Lins & S & $\mathrm{S}$ & $\mathrm{R}$ & $\mathrm{S}$ & S & Raça 8 \\
\hline PI-502 & Lins & S & $\mathrm{R}$ & $\mathrm{R}$ & $\mathrm{R}$ & $\mathrm{R}$ & Raça 0 \\
\hline PI-501 & Lins & S & $\mathrm{R}$ & $\mathrm{R}$ & S & $\mathrm{S}$ & Raça 2 \\
\hline PI-504 & Lins & S & $\mathrm{S}$ & $\mathrm{R}$ & S & S & Raça 8 \\
\hline PI-592-2 & Ibiúna & S & $\mathrm{R}$ & $\mathrm{R}$ & S & S & Raça 2 \\
\hline PI-592-1 & Ibiúna & S & $\mathrm{R}$ & $\mathrm{R}$ & $S$ & S & Raça 2 \\
\hline PI-592-4 & Ibiúna & S & $\mathrm{R}$ & $\mathrm{R}$ & S & S & Raça 2 \\
\hline PI-683 & Lins & S & $\mathrm{R}$ & $\mathrm{R}$ & S & S & Raça 2 \\
\hline PI-684 & Lins & S & $\mathrm{R}$ & $\mathrm{R}$ & S & S & Raça 2 \\
\hline PI-685 & Lins & $\mathrm{S}$ & $\mathrm{R}$ & $\mathrm{R}$ & $\mathrm{S}$ & $\mathrm{S}$ & Raça 2 \\
\hline PI-686 & Lins & $\mathrm{S}$ & $\mathrm{R}$ & $\mathrm{R}$ & $\mathrm{S}$ & $\mathrm{S}$ & Raça 2 \\
\hline P-3177 & Botucatu & $\mathbf{S}$ & $\mathbf{R}$ & $\mathbf{R}$ & $\mathbf{S}$ & $\mathbf{S}$ & Testemunha - Raça 2 \\
\hline Cl. 445 & SDA - Lins & $\mathbf{S}$ & $\mathbf{S}$ & $\mathbf{R}$ & $\mathbf{R}$ & $\mathbf{R}$ & Testemunha - Raça 1 \\
\hline
\end{tabular}

1/ = De acordo com Hibberd, 1987;

2/ = Denominação do gene de resistência;

3/ = S: Reação de Suscetibilidade; R: Reação de Resistência;

P.S. Reações avaliadas conforme a média obtida de 03 repetições de 06 plantas. 
Tabela 14. Experimento C - Matrizes de Similaridade obtidas a partir de 11 raças conhecidas e 13 isolados provenientes das regiões de Mogi das Cruzes, Guaíra e Piacatu

\begin{tabular}{|c|c|c|c|c|c|c|c|c|c|c|c|c|}
\hline \multirow[b]{2}{*}{ Isolados } & \multirow[b]{2}{*}{ P0 } & \multirow[b]{2}{*}{$\mathbf{P 1}$} & \multirow[b]{2}{*}{$\mathbf{P 2}$} & \multirow[b]{2}{*}{ P3 } & \multicolumn{3}{|c|}{ Reação das Raças } & \multirow[b]{2}{*}{ P7 } & \multirow[b]{2}{*}{ P8 } & \multirow[b]{2}{*}{ P9 } & \multirow[b]{2}{*}{ P10 } & \multirow[b]{2}{*}{ Obs. } \\
\hline & & & & & P4 & P5 & P6 & & & & & \\
\hline PI-513 & $0,25^{\mathrm{a}}$ & 0,33 & 0,50 & 0,50 & 0,00 & 0,00 & 0,00 & 0,50 & $1,00^{b}$ & 0,00 & 0,00 & Raça 8 \\
\hline PI-514 & 0,50 & 0,66 & 0,33 & 0,33 & 0,33 & 0,00 & 0,00 & 1,00 & 0,50 & 0,50 & 0,00 & Raça 7 \\
\hline PI-515-1 & 0,25 & 0,33 & 0,50 & 0,50 & 0,00 & 0,00 & 0,00 & 0,50 & 1,00 & 0,00 & 0,00 & Raça 8 \\
\hline PI-511 & 0,25 & 0,33 & 0,50 & 0,50 & 0,00 & 0,00 & 0,00 & 0,50 & 1,00 & 0,00 & 0,00 & Raça 8 \\
\hline PI-512 & 0,25 & 0,33 & 0,50 & 0,50 & 0,00 & 0,00 & 0,00 & 0,50 & 1,00 & 0,00 & 0,00 & Raça 8 \\
\hline PI-576 & 0,25 & 0,33 & 0,50 & 0,50 & 0,00 & 0,00 & 0,00 & 0,50 & 1,00 & 0,00 & 0,00 & Raça 8 \\
\hline PI-575 & 0,25 & 0,33 & 0,50 & 0,50 & 0,00 & 0,00 & 0,00 & 0,50 & 1,00 & 0,00 & 0,00 & Raça 8 \\
\hline PI-574 & 0,25 & 0,33 & 0,50 & 0,50 & 0,00 & 0,00 & 0,00 & 0,50 & 1,00 & 0,00 & 0,00 & Raça 8 \\
\hline PI-573 & 0,25 & 0,33 & 0,50 & 0,50 & 0,00 & 0,00 & 0,00 & 0,50 & 1,00 & 0,00 & 0,00 & Raça 8 \\
\hline PI-601 & 0,50 & 0,25 & 1,00 & 0,33 & 0,00 & 0,50 & 0,00 & 0,33 & 0,50 & 0,00 & 0,00 & Raça 2 \\
\hline PI-425 & 0,25 & 0,33 & 0,50 & 0,50 & 0,00 & 0,00 & 0,00 & 0,50 & 1,00 & 0,00 & 0,00 & Raça 8 \\
\hline PI-607 & 0,50 & 0,25 & 1,00 & 0,33 & 0,00 & 0,50 & 0,00 & 0,33 & 0,50 & 0,00 & 0,00 & Raça 2 \\
\hline PI-515-2 & 0,50 & 0,66 & 0,33 & 0,33 & 0,33 & 0,00 & 0,00 & 1,00 & 0,50 & 0,50 & 0,00 & Raça 7 \\
\hline P-3177 & 0,50 & 0,25 & 1,00 & 0,33 & 0,00 & 0,50 & 0,00 & 0,33 & 0,50 & 0,00 & 0,00 & Test. Raça 2 \\
\hline Cl. 445 & 0,75 & 1,00 & 0,25 & 0,66 & 0,66 & 0,00 & 0,33 & 0,66 & 0,33 & 0,33 & 0,00 & Test. Raça 1 \\
\hline
\end{tabular}

b- Valor 1,00 indica relação com a raça respectiva. 
Tabela 15. Experimento C - Caracterização das raças fisiológicas de Xanthomonas spp. conforme a reação de 13 isolados provenientes de Mogi das Cruzes, Guaíra e Piacatu, em 5 genótipos diferenciais

\begin{tabular}{|c|c|c|c|c|c|c|c|}
\hline \multirow[b]{2}{*}{ Isolado } & \multirow[b]{2}{*}{ Origem } & \multicolumn{5}{|c|}{ Genótipos Diferenciais $^{1}$} & \multirow[b]{2}{*}{ Resultado } \\
\hline & & $\begin{array}{c}\text { ECW } \\
(b s)\end{array}$ & $\begin{array}{c}\mathrm{ECW}-10 \mathrm{R} \\
(\text { Bs1 })^{\prime 2}\end{array}$ & $\begin{array}{c}\text { ECW-20R } \\
(B s 2)\end{array}$ & $\begin{array}{c}\text { ECW-30R } \\
\text { (Bs3) }\end{array}$ & $\begin{array}{c}\text { PI-235047 } \\
\text { (Bs4) }\end{array}$ & \\
\hline PI-513 & Mogi das Cruzes & $\mathrm{S}^{/ 3}$ & $\mathrm{~S}$ & $\mathrm{R}$ & $\mathrm{S}$ & $\mathrm{S}$ & Raça 8 \\
\hline PI-514 & Mogi das cruzes & $\mathrm{S}$ & S & $\mathrm{R}$ & $\mathrm{R}$ & S & Raça 7 \\
\hline PI-515-1 & Mogi das Cruzes & S & S & $\mathrm{R}$ & S & S & Raça 8 \\
\hline PI-511 & Mogi das Cruzes & S & S & $\mathrm{R}$ & S & S & Raça 8 \\
\hline PI-512 & Mogi das Cruzes & S & S & $\mathrm{R}$ & S & S & Raça 8 \\
\hline PI-576 & Mogi das Cruzes & S & S & $\mathrm{R}$ & S & S & Raça 8 \\
\hline PI-575 & Mogi das Cruzes & S & S & $\mathrm{R}$ & $S$ & $S$ & Raça 8 \\
\hline PI-574 & Mogi das Cruzes & S & S & $\mathrm{R}$ & $S$ & $S$ & Raça 8 \\
\hline PI-573 & Mogi das Cruzes & S & S & $\mathrm{R}$ & S & S & Raça 8 \\
\hline PI-601 & Guaíra & S & $\mathrm{R}$ & $\mathrm{R}$ & S & $S$ & Raça 2 \\
\hline PI-425 & Mogi das Cruzes & S & S & $\mathrm{R}$ & S & S & Raça 8 \\
\hline PI-607 & Piacatu & S & $\mathrm{R}$ & $\mathrm{R}$ & S & S & Raça 2 \\
\hline PI-515-2 & Mogi das Cruzes & S & S & $\mathrm{R}$ & $\mathrm{R}$ & S & Raça 7 \\
\hline P-3177 & Botucatu & $\mathbf{S}$ & $\mathbf{R}$ & $\mathbf{R}$ & $\mathbf{S}$ & $\mathbf{S}$ & Testemunha - Raça 2 \\
\hline Cl. 445 & SDA - Lins & $\mathbf{S}$ & $\mathbf{S}$ & $\mathbf{R}$ & $\mathbf{R}$ & $\mathbf{R}$ & Testemunha - Raça 1 \\
\hline
\end{tabular}

1/ = De acordo com Hibberd (1987);

2/ = Denominação do gene de resistência;

3/ = S: Reação de Suscetibilidade; R: Reação de Resistência;

P.S. Reações avaliadas conforme a média obtida de 3 repetições de 6 plantas. 


\subsection{Identificação das raças fisiológicas de Xanthomonas spp.}

De acordo com os resultados, a distribuição das raças fisiológicas identificadas, esteve disposta por regiões conforme mostra a Tabela 16.

Tabela 16. Distribuição de raças fisiológicas de Xanthomonas spp. caracterizadas, e respectivas regiões de origem

\begin{tabular}{|c|c|c|c|c|c|c|c|}
\hline \multirow[b]{2}{*}{ LOCAL } & \multicolumn{7}{|c|}{ NÚMERO DE ISOLADOS PERTENCENTES ÀS RAÇAS } \\
\hline & PO & $\mathbf{P 1}$ & $\mathbf{P 2}$ & P3 & P7 & P8 & $\begin{array}{l}\text { TOTAL/ } \\
\text { REGIÃO }\end{array}$ \\
\hline Piedade / SP & - & - & - & 01 & - & 05 & 06 \\
\hline Bragança Paulista/ SP & - & - & 01 & - & - & 03 & 04 \\
\hline Bacuriti / SP & - & 02 & 01 & - & - & 01 & 04 \\
\hline Lins / SP & 01 & - & 08 & - & - & 02 & 11 \\
\hline Ibiúna / SP & - & - & 03 & - & - & - & 03 \\
\hline Piacatu / SP & - & - & 01 & - & - & - & 01 \\
\hline Mogi das Cruzes/ SP & - & - & - & - & 02 & 09 & 10 \\
\hline Guaira / SP & - & - & 01 & - & - & - & 01 \\
\hline TOTAL DE RAÇAS & 01 & 02 & 15 & 01 & 02 & 20 & 41 \\
\hline
\end{tabular}

De acordo com os resultados dos 3 experimentos, foram observadas as seguintes raças dentre os isolados coletados nas seguintes regiões: Piedade - raças 3 e 8; Bragança Paulista - raças 2 e 8; Bacuriti - raças 1,2 e 8; Lins - raças 0, 2 e 8; Ibiúna e Piacatu - raça 2; Mogi das Cruzes - raças 7 e 8 e Guaíra - raça 2. Portanto, considerando-se a porcentagem de ocorrência no universo dos isolados coletados: 49\% comportaram-se como raça $8 ; 37 \%$ como raça $2 ; 5 \%$ como raça $7 ; 5 \%$ como raça 1; 2\% como raça 3 e outros $2 \%$ como raça 0. A raça 8 apresentou maior freqüência (49\%), seguida da raça 2 (37\%), no total de isolados estudados; a raça 2 apresentou maior 
distribuição (75\%), seguida da raça 8 (62,5\%), entre as regiões estudadas; e as raças 0, 1, 3 e 7 foram as menos prevalentes.

A identificação dos isolados realizada através da inoculação na série diferencial permitiu a classificação dos isolados de Xanthomonas spp. em nível de raças. Neste caso, o conhecimento da relação gene-a-gene proposta por Flor (1942) contribuiu para a identificação através da expressão dos genes correspondentes de avirulência do patógeno, e de hipersensibilidade do hospedeiro.

A ocorrência das raças 7 e 8 corresponde ao primeiro relato destas raças infectando naturalmente o pimentão no Brasil. A evidência da presença da raça 8 foi observada em tomate pela primeira vez juntamente com a raça 2 na Região Nordeste e, juntamente com a raça 7 no Brasil-Central (Quezado-Duval, 2003). A predominância na freqüência da raça 8 entre os isolados avaliados, apesar da maior distribuição da raça 2 nas regiões (75\%), pode significar um relacionamento direto entre estas raças, pois a raça 2 poderia se transformar em raça 8 através da perda do gene avrBs1 localizado em plasmídeo (Minsavage et al., 1990). Ainda outra possibilidade há que ser considerada, a de que as raças 1 e 3 tenham passado a ser classificadas respectivamente como raças 7 e 8 (Ritchie et al., 1998; Sahin \& Muller, 1998). A partir da identificação do gene avrBs4, através do PI-235047, foi possível a identificação das raças 7 e 8, que diferem das raças 1 e 3 somente pela presença deste gene. A identificação das raças 0, 1, 2 e 3 em regiões produtoras do Estado de São Paulo, está de acordo com os resultados apresentados no relato de Bouzar et al. (1994) que, porém, identificou isolados principalmente do Estado do Paraná.

Este trabalho indicou a predominância da raça 8, seguida da raça 2, contrariando muitos trabalhos realizados com o Gênero Xanthomonas em pimentão que atestam a predominância das raças 1 e 3 no campo em outras regiões estudadas fora do Brasil (Bouzar et al., 1994; Buonario et al., 1994; Lee \& Cho, 1996; Sahin \& Miller, 1996). Porém, até então, não eram conhecidas técnicas de identificação que incluíam o uso do PI-235047 (Sahin \& Muller, 1998), pois conforme comentado, a raça 3 pode ter sido a 
partir de então, classificada como raça 8. A ocorrência da raça 2, está de acordo com outros autores, que relataram a ocorrência da raça 2, além das raças 1 e 3, como as raças mais comuns (Kearney et al., 1988).

A predominância das raças 2 e 8 indicou a prevalência dos genes avrBs2 (raças 2 e 8) e avrBs1 (raça 2) nos isolados. Conforme Kearney et al. (1988), a maioria das estirpes carrega o gene de avirulência $a v r B s 2$, o que está de acordo com as duas raças predominantes neste trabalho. Além disso, o gene avrBs2 não teve a sua presença confirmada no plasmídeo (Swords et al., 1996) e as estirpes que possuem este gene permanecem agressivas no campo, ou seja, estas raças podem ser mais estáveis, aumentando a sua ocorrência em nível de campo.

A distribuição de isolados em estudos anteriores realizados em tomate por Quezado-Duval (2003), inferiram a ocorrência das raças: 2 e 8 (regiões Nordeste e Brasil-Central); e 7 (Brasil-Central), indicando as raças 2 e 8 como as raças de maior evidência entre os isolados avaliados, o que concorda com os resultados deste trabalho (raça 8 - 49\%, raça 2 - 37\%). Não foi considerada representativa a ocorrência dos isolados nas regiões estudadas, em virtude da não haver um número proporcional de isolados entre as regiões. Porém, foi possível, dentro das limitações impostas pela amostragem, avaliar a ocorrência dos isolados nas regiões onde foram coletados, independente da representatividade dos mesmos.

O relato da raça 8, neste trabalho, pode significar um evento de introdução relativamente recente, que pode ter ocorrido por mutação, pois a raça 2 poderia transformar-se em raça 8 através da perda do gene avrBs1 localizado em plasmídeo (Minsavage et al., 1990), ou ainda, a bactéria poderia ter entrado no país através de sementes contaminadas. Conforme comentado também (Introdução - ítem 1), as principais cultivares plantadas no Brasil não tem resistência à Xanthomonas spp., o que favoreceria mutações ao acaso no campo, não favorecidas por pressão de seleção exercida pelo hospedeiro. 
O direcionamento para o desenvolvimento e recomendação de cultivares que carregam o gene Bs2, que confere resistência às raças $0,1,2,3,7$ e 8, está de acordo com as informações da literatura. Cultivares que carregam o gene Bs2 são considerados os mais promissores, pois conferem resistência às raças mais comuns, e também às reportadas neste trabalho. Além disso, Bs2 também é considerado o gene mais durável, pois a maioria das estirpes carrega o gene de avirulência avrBs2. As cultivares com o gene Bs2 devem ser recomendadas com cautela, porém, para as regiões e/ ou épocas excessivamente quentes, o que poderia “quebrar” o gene de resistência (Romero et al., 2002). Neste caso, é importante se ressaltar a vantagem ou a cautela de se recomendar cultivares com resistência específica para regiões com condições ambientes específicas.

A variabilidade das raças fisiológicas, de acordo com os estudos realizados até aqui, aparentemente, independe da espécie de Xanthomonas spp.. Este estudo abre perspectivas para a identificação das espécies desta bactéria em pimentão, e sua relação com os genes avr e Hrp. 


\section{CONCLUSÕES}

Foram identificadas seis raças fisiológicas de Xanthomonas spp. patogênicas ao pimentão (raças 0,1,2,3,7 e 8) distribuídas nas regiões de Piedade, Bragança Paulista, Bacuriti, Lins, Ibiúna, Piacatu, Mogi das Cruzes e Guaíra, no Estado de São Paulo.

Considera-se aqui, o primeiro relato das raças 7 e 8, infectando naturalmente o pimentão no Brasil.

Sugere-se o desenvolvimento e a recomendação de cultivares de pimentão com o gene Bs2 para as regiões estudadas do Estado de São Paulo, pois este gene confere resistência às raças 0,1 , 2, 3, 7 e 8 do patógeno, identificadas nestas regiões. 


\section{REFERÊNCIAS BIBLIOGRÁFICAS}

BASHAN, Y.; DIAB, S.; OKON, Y. Survival of Xanthomonas campestris pv. vesicatoria in pepper seeds and roots in symptomless and dry leaves in non-host plants and in the soil. Plants and Soil, v.68, p.161-170, 1982.

BATISTA, A.C. Principais doenças de plantas cultivadas no Nordeste. Pernambuco: Secretaria de Agricultura, Indústria e Comércio do Estado de Pernambuco, 1982. $105 \mathrm{p}$.

BONGIOLO NETO, A.; REIFSCHNEIDER, F. J. B.; TAKATSU, A. Levantamento de grupos de Xanthomonas campestris pv. vesicatoria no Brasil. Fitopatologia Brasileira, v.11, n. 2, p.881-889, 1986.

BOUZAR, H.; JONES, J.B.; STALL, R.E.; HODGE, N.C.; MINSAVAGE, G.V.; BENEDICT, A.A.; ALVAREZ, A.M. Physiological, chemical, serological, and pathogenic analyses of a worldwide collection of Xanthomonas campestris pv. vesicatoria. Phytopathology, v.84, p.663-671, 1994.

BOUZAR, H.; JONES, J.B.; STALL, R.E.; LOWS, F.J.; SCHNEIDER, M.; RADEMAKER, J.L.W.; DE BRUIJN, F.J.; JACKSON, L.E. Multiphasic analysis of Xanthomonads causing bacterial spot disease on tomato and pepper in Caribbean and Central America: evidence for common lineages within and between countries. Phytopathology, v.89, n.4, p.328-335,1999. 
BUONARIO, R.; STRAVATO, V.M.; SCORTICHINI, M. Characterization of Xanthomonas campestris pv. vesicatoria from Capsicum annuum L. In Italy. Plant Disease, v. 78. n. 3, p. 296-299, 1994.

BURKHOLDER, W.H.; LI, C.C. Variation in Phytomonas vesicatoria. Phytopathology, v.31, n.8, p.753-755, 1941.

CANTEROS, B.I.; MINSAVAGE, G.V.; JONES, J.B.; STALL, R.E. Diversity of plasmid in Xanthomonas campestris pv. vesicatoria. Phytopathology, v.85, p.12601265, 1995.

CANTEROS, B. I.; MINSAVAGE, G. V.; BONAS, V.; PRING, D.; STALL, R. E. A gene from Xanthomonas campestris pv. vesicatoria that determines avirulence in tomato is related to avrBS3. Molecular and Plant-Microbe Interactions, v.4, n.6, p.628-632, 1991.

CARLINI-GARCIA, L.A. Estudo da estrutura genética populacional através de marcadores moleculares. Piracicaba, 1998. 118p. Dissertação (Mestrado) - Escola Superior de Agricultura “Luiz de Queiroz”, Universidade de São Paulo.

COOK, A.A. Characterization of hypersensitivity in Capsicum annuum induced by the tomato estirpe of Xanthomonas vesicatoria. Phytopathology, v.63, p.1260-1265, 1973.

COOK, A.A.; STALL. R.E. Effects of watersoaking on response to Xanthomonas vesicatoria in pepper leaves. Phytopathology, v.67, p.1101-1103, 1977.

DAHLBECK, D.; STALL, R.E. Mutations for change of race in cultures of Xanthomonas vesicatoria. Phytopathology, v. 69, p. 634, 1979

DAHLBECK, D.; STALL, R.E.; JONES, J.P. The efect of vertical and horizontal resistance on development of bacterial spot in pepper. Plant Disease Reporter, v.63, p. 332-335, 1979. 
DIAB, S.; BASHAN, Y.; OKON, Y.; HENIS, Y. Effects of relative humidity on bacterial scab caused by Xanthomonas campestris pv. vesicatoria on pepper. Phytopathology, v.72, p.1257-1260, 1982.

DOIDGE, E.M. A tomato canker. Journal of Department of Agriculture Union South Africa, v.1, p.718-721, 1920.

DOIDGE, E.M. A tomato canker. Annal of Applied Biology, v.7, p.407-430, 1921.

DUNN, G.; EVERITT, B.S. An introduction to mathematical taxonomy. New York: Cambridge University Press, 1980. 152 p.

DYE, D.W. Cultural and biochemical reaction of additional Xanthomonas species. New Zealand Journal of Science, v.9, p.913-919, 1966.

DYE, D.W.; STARR, M.P.; STOLP, H. Taxonomic clarification of Xanthomonas vesicatoria based upon host specificity, bacteriophage sensitivity, and cultural characteristics. Phytopathology, v.51, p. 394-407, 1964.

ELLIOT, C. Manual of bacterial plant pathogen. Waltham: Crhonica Botanica Press, 1951. $186 \mathrm{p}$.

FLOR, H.H. Inheritance of pathogenicity of Melampsora lini. Phytopathology, v. 32, p. 653-669, 1942.

FNP CONSULTORIA \& COMERCIO. AGRIANUAL 2003: anuário da agricultura brasileira. São Paulo, 2003. 544p.

FRENHANI, A.A. Caracterização de uma cepa de Xanthomonas vesicatoria (DOIDGE) Dowson isolada de uma cultura comercial de pimentão (Capsicum annuum L), localizada em Campinas, S. P. O Biológico, v.35, p.36-40, 1969.

GARDNER, M.W.; KENDRICK, J.B. Bacterial Spot of tomato. Journal of Agriculture, v.21, p.123-156, 1921. 
GARDNER, M.W.; KENDRICK, J.B. Bacterial spot of tomato and pepper. Phytopathology, v.13, n.7, p.307-315, 1923.

GOODMAN, R.N.; NOVACKY, A. The hypersensitive reaction in plants to pathogens: a resistance phenomenon. St. Paul: APS Press, 1994. 244 p.

GOPALAN, S.; YANG HE, S. Bacterial genes involved in the elicitation of hypersensitive response and pathogenesis. Plant Disease, v.80, p.604-610, 1996.

HAYWARD, A.G.; WATERSON, J.M. Xanthomonas vesicatoria: descriptions of pathogenic fungi and bacteria. Kew Surrey: Commonwealth Mycological Institute Press, 1964. 2 p.

HIBBERD, A.M.; STALL, R.E.; BASSET, M.J. Different phenotypes associated with incompatible races and resistance genes in bacterial spot disease of pepper. Plant Disease, v.71, p.1075-1078, 1987.

HIGGINS, B.B. The bacterial spot of pepper. Phytopathology, v.12, p.501-516, 1922.

JACCARD, P. Nouvelles recherches sur la distribution florale. Bulletin de la Societé Vanddoise des Sciences Natureles, v. 44, p. 223-270, 1908.

JONES, J.B.; STALL, R.E.; BOUZAR, H. Diversity among Xanthomonads pathogenic on pepper and tomato. Annual Review of Phytopathology, v.36, p.41-58, 1998.

JONES, J.B.; LACY, G.H.; MINSAVAGE, G.V.; STALL, R.E.; SCHAAD, N.W. Bacterial spot - Worldwide distribution, importance and review. In: INTERNATIONAL SYMPOSIUM ON TOMATO DISEASES 1.; ANNUAL TOMATO DISEASE WORKSHOP, 19., Orlando, 2004. Program and Abstract Book. Orlando: ISHS, 2004. p.21.

JONES, J.B.; MINSAVAGE, G.V.; ROBERTS, P.D.; JOHNSON, R.R.; KOUSIK, C. S.; SUBRAMANIAN, S.; STALL, R.E. A non-hypersensitive in pepper to the 
bacterial spot pathogen is associated with two recessive genes. Phytopathology, v.92, p.273-277, 2002.

JONES, J.B.; BOUZAR, H.; STALL, R.E.; ALMIRA, E.C.; ROBERTS, P.D.; BOWEN, B.W.; SUDBERRY, P.M.; STRICKLER, P.M.; CHUN, J. Systematic analysis of xanthomonads (Xanthomonas spp.) associated with pepper and tomato lesions. International Journal of Systematic Bacteriology, v.50, n.5, p.1211-1219, 2000.

KEARNEY, B.; RONALD, P.C.; DAHLBECK, D.; STASKAWICZ, B.J. Molecular basis for the evasion of plant host defence in bacterial spot disease of pepper. Nature, v. 332, p. 541-543, 1988.

KIMURA, O. Enfermidades bacterianas do pimentão. Informe Agropecuário, v.10, p.39-41, 1984.

KIMURA, O. Fitoalexinas e resistência de pimentão (Capsicum annuum L.) a Xanthomonas campestris pv. vesicatoria (DOIDGE) Dye. Viçosa, 1986. 94p. Tese (Doutorado) - Universidade Federal de Viçosa.

KIMURA, O.; ROBBS, C. F.; AKIBA, F.; TERANISHI, J. Identificação de um novo grupo de Xanthomonas vesicatoria (DOIDGE) Dowson infectando a Berinjela (Solanum melongena). Revista da Sociedade de Fitopatologia, v.9, n.3, p.5, 1976. /Apresentado ao 9. Congresso Brasileiro de Fitopatologia, Piracicaba, 1976Resumo/.

KIMURA, O.; STRALIOTTO, R.; SUDO, A.; MURANAGA, M. Eficiência de transmissão de Xanthomonas campestris pv. vesicatoria em sementes de pimentão. Fitopatologia Brasileira, v.14, p.126, 1989. /Apresentado ao 22. Congresso Brasileiro de Fitopatologia, Campinas, 1989 - Resumo/.

KIMURA, O.; ROBBS, C. F.; RIBEIRO, R. L. D.; AKIBA, F.; SUDO, S. Identificação de patotípos de Xanthomonas campestris pv. vesicatoria (DOIDGE) Dowson, 
ocorrendo na região centro-sul do Brasil. Arquivos do Instituto Biológico, v.39, p.43-49, 1972.

KLEMENT, Z. Rapid detection of the patogenicity of phytopatogenic Pseudomonads. Nature, v.199, p.299-300, 1963.

KOBORI, R. F.; WIERZBICKI, R. Identificação de raças de Xanthomonas vesicatoria em pimentão na região de Lins-SP. Summa Phytopathologica, v. 26, p.130, 2000. / Apresentado 23. Congresso Paulista de Fitopatologia, Campinas, 2000 - Resumo/.

KOUSIK, C.S.; RITCHIE, D.F. Development of bacterial spot on near-isogenic lines of bell pepper carrying gene pyramids composed of defeated major resistance genes. Phytopathology, v. 89, p. 1066-1072, 1999.

LINDGREN, P.B.; PEET, R.C.; PANOPOULOS, N.J. Gene-cluster of Pseudomonas syringae pv. phaseolicola controls pathogenicity of bean plants and hypersensitivity on non host plants. Journal of Bacteriology, v.168, p. 512-522, 1986.

LOPES, C.A.; AVILA, A.C. Doenças do pimentão: diagnose e controle. Brasília: Embrapa Hortaliças, 2003. v.1, 96 p.

LOPES, C.A.; QUEZADO-SOARES, A.M. Doenças bacterianas das hortaliças, diagnose e controle. Brasília: Embrapa SPI, 1997. 72 p.

LUCERO, H. Mancha bacteriana del tomato (Xanthomonas vesicatoria) em Mendoza. Idia, n.240, p.41-42, 1967.

MARIANO, R. L. R. Manual de práticas em fitobacteriologia. Recife: O Autor, 2000. cap.7, p. 65-66: Reação de hipersensibilidade a bactérias fitopatogênicas.

MARINGONI, A.C. Caraterização de Xanthomonas campestris pv. vesicatoria (DOIDGE) Dye de pimentão (Capsicum annuum L.) e de tomateiro (Lycopersicon esculentum Mill.) através de patogenicidade, sorologia, hidrólise de amido e 
sensibilidade a drogas. Piracicaba, 1986. 80p Dissertação (Mestrado) - Escola Superior de Agricultura “Luiz de Queiroz”, Universidade de São Paulo.

MINSAVAGE, G.V.; DAHLBECK, D.; WHALEN, M.C.; KEARNEY, B.; BONAS, V.; STASKAWICZ, B.J.; STALL, R.E. Gene for-gene relation ships specifying disease resistance in Xanthomonas campestris pv. vesicatoria - Pepper Interactions. Molecular and Plant-Microbe Interactions, v.3, n.1, p.41-47, 1990.

MORTON, D.J. Comparison of three serological procedures for identifying Xanthomonas vesicatoria in pepper leaves. Phytopathology, v.55, p.421-424, 1965.

NAYUDU, M.Y.; WALKER, J.C. Bacterial spot of tomato as influencied by temperature and by age and nutrition of the host. Phytopathology, v.56, p. 360-364, 1960.

NIEPOLD, F.; ANDERSON, D.; MILLS, D. Cloning determinants of pathogenesis from Pseudomonas syringae pv. syringae. Proceedings of the National Academy of Sciences of the USA, v. 82, p.406-410, 1985.

O’GARRO, L.W.; GORE, J.P.; FERGUSON E. Races of Xanthomonas campestris pv. vesicatoria overcoming the gene BS2 for Bacterial Spot resistance in pepper, prevalent on Capsicum chinense in Barbados and Grenada and weakly pathogenic on Bell pepper and tomato in the field. Plant Pathology, v.48, p.588-594, 1999.

PERNEZNY, K.; STALL, R.; SHULER, K.; COLLINS, J.; HEWITT, M. Results of a survey of bacterial spot races (Xanthomonas campestris pv. vesicatoria) in pepper in South Florida, spring 1998. Palm Beach County Extension Report (PBCER), p. 147-149, 1998.

PORHONEZNY, K.; STALL, R.E.; SUBRAMANYA, S.; SHULER, K.D. Integrated control of bacterial spot on peppers. Florida Grower and Rancher, v. 86, n. 6, p.8, 1993. 
QUEZADO-DUVAL, A.M. Diversidade de Xanthomonas spp. associados à manchabacteriana em tomateiro para processamento industrial no Brasil. Piracicaba, 2003. 111p. Tese (Doutorado) - Escola Superior de Agricultura “Luiz de Queiróz”, Universidade de São Paulo.

REIFSCHNEIDER, F.J.B.; BONGIOLO NETO, A.; TAKATSU, A. Reappraisal of Xanthomonas campestris pv. vesicatoria strains: their terminology and distribution. Fitopatologia Brasileira, v.10, n.2, p.201 - 204, 1985.

RITCHIE, D.F.; KOUSIK, C.S.; PAXTON, T. C. Response of bacterial spot pathogen strains to four major resistance genes in pepper. In: THE NATIONAL PEPPER CONFERENCE, Tampa, 1998. Proceedings. Tampa: FFVA, 1998. p.14.

ROBBS, C. F. A “Mancha Bacteriana”do pimentão (Capsicum annuum L.) Agricultura e Pecuária. Rio de Janeiro: Editora Terra, 1953. p. 25-32.

ROBBS, C.F.; NETO, J.R.; RIBEIRO, R.L.D.; KIMURA, O. Annotated list of bacterial plant pathogens in Brazil. In: INTERNATIONAL CONFERENCE ON PLANT PATHOGEnIC BACTERIA, 5., Colômbia, 1981. Proceedings. Cali: DDA Press, 1981. p. 601-613.

ROMEIRO, R.S. Bactérias fitopatogênicas. Viçosa: UFV, 2000. cap. 5, p.131: Sintomatologia.

ROMERO, A.M.; KOUSIK, C.S.; RITCHIE, D.F. Temperature sensitivity of the hypersensitive response of bell pepper to Xanthomonas axonopodis pv. vesicatoria. Phytopathology, v.92, n.2, p.197-203, 2002.

SAHIN, F. Detection, identification and characterization of strains of Xanthomonas campestris pv. vesicatoria by tradicional and molecular methods, and resistance in Capsicum species to Xanthomonas campestris pv. vesicatoria pepper race 6 . Columbus, 1997. 182 p. Thesis (Ph.D.) - The Ohio State University. 
SAHIN, F.; MILLER, S.A. Characterization of Ohio strains of Xanthomonas campestris pv. vesicatoria, causal agent of bacterial spot of pepper. Plant Disease, v.80, n.7, p.773-778, 1996.

SAHIN, F.; MILLER, S.A. Resistance in Capsicum pubescens to Xanthomonas campestris pv. vesicatoria pepper race 6. Plant Disease, v.82, n.7, p.794-799, 1998.

SALLES, M.R.M.; KIMURA, O.; RIBERO, R.L.D.; AKIBA, F. Sementes: importante fonte de inóculo de Xanthomonas campestris pv. vesicatoria para culturas comerciais de pimentão no Brasil. Fitopatologia Brasileira, v.16, n.1, p.41, 1991. /Apresentado ao 24. Congresso Brasileiro de Fitopatologia, Belo Horizonte, 1991 Resumo/.

SCHAAD, N.W.; JONES, J.B.; CHUN, W. Laboratory guide for identification of plant pathogenic bacteria. St. Paul: APS Press, 2001. 373p.

SHERBAKOFF, C.B. Report of the associate plant pathologist. Agricultural Journal, v. 3, p. 1916-1917, 1918.

STALL, R.E.; COOK, A.A. Evidence that bacterial contact with the plant cell is necessary for the hypersensitive reaction but not the susceptible reaction. Physiological Plant Pathology, v.14, p.77-84, 1979.

STALL, R.E.; BEAULIEU, C.; EGEL, D.; HODGE, N.C.; LEITE, R.P.; MINSAVAGE, G.V.; BOUZAR, H.; JONES, J.B.; ALVAREZ, A.M.; BENEDICT, A.A. Two genetically diverse groups of estirpes are included in a pathovar of Xanthomonas campestris. International Journal of Systematic Bacteriology, v.44, n.1, p.47-53. 1994.

STASKAWICZ B.; TAMAKI S.; DAHLBECK, D.; KEEN, N.T. Characterization and expression of two avirulence genes cloned from Pseudomonas syringae pv. glycinea. Journal of Systematic Bacteriology, v.170, p.4846-4854, 1988. 
SUSLOW, T.V.; SCRHOTH, M.N.; ISAKA, M. Aplication of a rapid method for Gram differentiation of plant pathogenic and saprophytic bacteria without staining. Phytopathology, v.72, p.917-918, 1982.

SUTIC, D. Baktorioze crvenog patlidzana [Tomato bacteriosis]. The Review of Applied Mycology, v.36, p.734-735, 1957.

SWORDS, K.M.M.; DAHLBECK, D.; KEARNEY, B.; ROY, M.; STASKAWICZ, B.J. Spontaneous and induced mutations in a single open reading frame to both virulence and avirulence in Xanthomonas campestris pv. vesicatoria avrBs2. Journal of Bacteriology, v.178, p.4661-4669, 1996.

TAI, T.H.; DAHLBECK, D.; CLARK, E.T.; GAJIWALA, P.; PASION, R.; WHALEN, M. C.; STALL, R.E.; STASKAWICZ, B.J. Expression of resistance the Bs2 pepper gene confers resistance to bacterial spot disease in tomato. Proceedings of the National Academy of Science of the USA, v.96, n.24, p.14153-14158, 1999.

VAUTERIN, L.; RADEMAKER, J.; SWINGS, J. Synopsis on the taxonomy of the genes Xanthomonas. Phytopathology, v.90, p.677-682, 2000.

VAUTERIN, L.; HOSTE B.; KERSTERS, K.; SWINGS, J. Reclassification of Xanthomonas. International Journal of Systematic Bacteriology, v.45, n.3, p.472-489, 1995.

VAUTERIN, L.; SWINGS, J.; KERSTERS, K.; GILLIS, M.; MEW, T.W. Towards an improved taxonomy of Xanthomonas. International Journal of Systematic Bacteriology, v.40, p.312-316, 1990.

WALKER, J.C. Use of environmental factors in screening for disease resistance. Annual Review of Phytopathology, v.3, p.197-208, 1965.

WALKER, J.C.; PATEL, P.N. Splash dispersal and wind as factors in epidemiology of halo blight on bean. Phytopathology, v.54, p.140-141, 1964. 
YOUNG, J.M.; SADDLER, G.S.; TAKIKAWA, U.; DE BOER, S.H.; VAUTERIN, L.; GARDAN, L.; GVOZDYAK, R.I.; STEAD, D.E. Names of plant pathogenic bacteria 1864-1995. Review of Plant Pathology, v.75, n.9, p.721-763, 1996. 